\title{
Die Darfur-Krise im Sudan und das Völkerrecht: Eine Herausforderung für die Vereinten Nationen (UN) und den Internationalen Strafgerichtshof (ICC)*
}

\author{
Von Hatem Elliesie, Berlin
}

\section{A. Einleitung}

Am 9. Januar 2005 wurde in der kenianischen Hauptstadt Nairobi das Comprehensive Peace Agreement (CPA) durch den damaligen 1. Vizepräsidenten der Republik Sudan, 'Alī 'Utmān Muhammad Țaha, und den inzwischen verstorbenen Vorsitzenden der Sudanese People's Liberation Movement (SPLM), Dr. John Garang de Mabior ${ }^{\dagger}$, unterzeichnet. Damit wurde der bisher maßgebliche Nord-Süd-Bürgerkrieg in formeller Hinsicht beendet. Entgegen der Bezeichnung als Comprehensive Peace Agreement hat die Friedensvereinbarung bisher jedoch weder de facto noch de jure die Gestalt eines umfassenden, gesamtsudanesischen Abkommens angenommen. Ohne die überaus positive Errungenschaft im Friedensprozess zwischen der Government of Sudan (GoS) und der SPLM zu schmälern, ist festzustellen, dass die Interessen weiterer Volksgruppen, unter anderem in den weitgehend marginalisierten östlichen und westlichen Regionen des größten Flächenstaates Afrikas, bislang nicht adäquat implementiert wurden. Bewaffnete Auseinandersetzungen in unterschiedlichster Intensität zu Lasten der Zivilbevölkerung flackern immer wieder auf. Diese Zentrum-Peripheriekonflikte mit teilweise wechselnden Allianzen werden daher auch als „,chronische humanitäre und politische Krise mit multidimensionaler Konfliktlage“ be-

* Dieser Artikel ist eine mehrfach überarbeitete und aktualisierte Fassung eines von dem Verfasser am 12. Januar 2006 an der rechtswissenschaftlichen Fakultät der Universität Hannover gehaltenen Vortrags im Rahmen der Veranstaltung ,Die Reform der Vereinten Nationen - Bilanz und Perspektiven: Rolle und Funktionen der Vereinten Nationen bei der Abwehr neuer Gefährdungslagen“. Auch dieser Beitrag kann wegen der besonderen Eigendynamik der Entwicklungen im Sudan nur als eine aktuelle Bestandsaufnahme verstanden werden (Vgl. Hatem Elliesie, Friedensprozess und Verfassungsentwicklung im Sudan, VRÜ 38 (2005), S. 276, 277 (Fn. 5)). In zeitlicher Hinsicht wird darauf hingewiesen, dass die Unterzeichnung des Eastern Sudan Peace Agreements (ESPA) in Asmara (Ausführlich dazu Haddas Erətra, Ausgabe vom 14. Oktober 2006, Asmara 2006, S. 1-3) zum Anlass genommen wurde, die relevanten Geschehnisse bis ausschließlich zum 14. Oktober 2006 aufzunehmen.

Seit dem CPA 1. Vizepräsident der Republik Sudan - verunglückte nur drei Wochen nach seinem Amtsantritt bei einem Hubschrauberabsturz am 30. Juli 2005 tödlich. Sein Nachfolger ist nun Salva Kiir Mayardit. 
schrieben. ${ }^{1}$ Diametral zu den hoffnungsvollen Entwicklungen im Nord-Süd-Friedensprozess unter der Ägide der Intergovernmental Authority on Development (IGAD) rief vor allem die humanitäre Krise in der westlichen Region Darfur Erinnerungen an den verheerenden Genozid in Ruanda von 1994 wach, was gleichwohl nur auf zögerliche Resonanz der internationalen Staatengemeinschaft stieß. Infolgedessen werden in dieser Abhandlung zunächst kurz die maßgeblichen Hintergründe der Konfliktlage in Darfur dargelegt, bevor schließlich näher auf die Rolle der Vereinten Nationen (UN) und des Internationalen Strafgerichtshofs (IStGH/ICC) eingegangen werden kann.

\section{B. Hintergründe zur Konfliktlage in Darfur}

\section{Zur Vorgeschichte der Eskalation im Westsudan}

Die Bezeichnung Darfur (Dārfū ${ }^{2}$ ) wird meist zusammenfassend für das Gebiet der sudanesischen Provinzen (wilāyāt) Nord-Darfur (Šamāl Dārfūr), West-Darfur (Ġarb Dārfūr) und Süd-Darfur ( $\breve{G} a n \bar{u} b$ Dārfūr $)^{3}$ verwendet, ${ }^{4}$ deren Gesamtfläche mit etwas über $509.000 \mathrm{~km}^{2}$ circa der Größe Frankreichs entspricht. Das von unterschiedlichen islamischen Bevölkerungsgruppen besiedelte und bis 1916 unabhängige Sultanat wurde zwar organisatorisch in den (britischen) Sudan integriert, ${ }^{5}$ der Westsudan blieb jedoch sowohl vor, als

So Marina Peter, Studien zur länderbezogenen Konfliktanalyse - Sudan [hrsg. vom Deutschen Entwicklungsdienst und der Friedrich-Ebert-Stiftung], Bonn 2004, S. 13.

oder Dār Fūr; arab. „Land der Fur“ - eine von zahlreichen angestammten Volksgruppen, die sich selbst auch als fò̀rà bezeichnet.

Kurze Ausführungen zu den administrativen Zuständigkeiten liefert Atta El-Battahani, Ideologische, expansionistische Bewegungen und historische indigende Rechte in der Region Darfur, Sudan: Vom Massenmord zum Genozid, Zeitschrift für Genozidforschung, 5 (2004/2), S. 8, 11 [aus dem Englischen von Kristin Platt], wobei jedoch darauf hingewiesen werden muss, dass es sich bei Nord-, West-, und Süd-Darfür nicht um (Bundes-)Staaten im staatsorganisationsrechtlichen Sinne handelt, sondern um wilāyāt, also genauer genommen mit Verwaltungsbezirke oder Provinzen umschrieben werden müssten, zudem jedenfalls der (Nord-)Sudan bisher nicht föderal gegliedert ist.

Vgl. Artikel 108 lit. 1, lit. q sowie lit. f der sudanesischen Verfassung von 1998. In der arabischen Fassung entsprechend Art. 108 lit. $m$, lit. $s$ lit. $z$. In dem sog. Draft Constitutional Text vom 16. März 2005 sind in Artikel 177 diesbezüglich bisher allerdings noch keine vergleichbaren Bezeichnungen verankert worden. Sie sollen nach Maßgabe des Artikels 177 Absatz 2 vom nationalen Gesetzgeber beschlossen werden.

Detaillierter zur Geschichte Darfurs siehe Peter Holt, DÀR FÙR, in: The Encyclopedia of Islam, New Edition, Volume II (C-G), Leiden/London 1965, S. 121-125. 
auch nach der Unabhängigkeit von der nationalen Entwicklung weitgehend abgekoppelt und wurde politisch und ökonomisch vernachlässigt. ${ }^{6}$

\section{Maßgebliche extern-regionale Faktoren des Darfurkonflikts}

Historisch betrachtet hatten die Grenzstreitigkeiten zwischen dem Tschad und Libyen um den Aouzou-Streifen ${ }^{7}$ nachhaltigste Auswirkungen auf die jüngsten Eskalationen in der Darfur-Region. ${ }^{8}$ Gepaart mit bewaffneten tschadischen Bürgerkriegsparteien ${ }^{9}$ wie der FROLINAT (Front de Libération Nationale du Tchad), welche Darfur auch als Rückzugsgebiet und teilweise Kampfgebiet nutzte, ${ }^{10}$ waren die Folgen dieser militärischen Auseinandersetzungen erhebliche Waffenströme nach Darfur. ${ }^{11}$ Diese Auseinandersetzungen gingen weniger mit der typischen islamideologischen Rhetorik des Nord-Süd-Konflikts einher, ${ }^{12}$ sondern wurden vielmehr von einer rassenideologischen Polemik begleitet, ${ }^{13}$ die ihrerseits die Spannungen zwischen einzelnen Volksgruppen in der Region um (Weide-)Land, Wasser und Ressourcen, insbesondere durch eine missglückte Landreform und die Dürreperio-

Gérard Prunier, Darfur - The Ambiguous Genocide, New York 2005, S. x; Alex de Waal, Who are the Darfurians? Arab and African Identities, Violence and External Engagement, African Affairs 104/415, Oxford April 2005, S. 181, 192, 203; Thomas Schmidinger, Sudan - Der Staat als Warlord, Blätter für deutsche und internationale Politik, 2005, S. 194 ff; Atta El-Battahani, a.a.O. (Fn. 3), S. 15 ff; Marina Peter, a.a.O. (Fn. 1), S. 15.

Am 1. Januar 1935 wurden Tripolitanien, Fezzan und die Cyrenaika zur italienischen Kolonie Libyen vereinigt. Italien und Frankreich vereinbarten daraufhin eine Grenzziehung zwischen der Kolonie Libyen und dem französisch-kontrollierten Gebiet des heutigen Tschad. Der Vertrag wurde aber nicht ratifiziert. Mu'ammar al-Qad solini im Dezember 1938 auf den deutlich größeren Teil des auch als Aozou oder Auzou bezeichneten Territoriums wieder. Siehe dazu ausführlicher Bernard Lanne, Tchad-Libye: La querelle des frontières, 2. Auflage, Paris 1986, insb. S. 228 ff. Siehe auch John Wright, Libya, Chad and the Central Sahara, Totowa 1989, S. 126-133.

Vergleiche auch Gérard Prunier, a.a.O. (Fn. 6), 'The Chadian-Libyan factor: a fundamental element of destabilization', S. 42-47.

9 Zur gegenwärtigen Krise im Tschad und deren Interdependenz mit der Darfur-Krise im Sudan siehe Simon Massey / Roy May, The Crisis in Chad, African Affairs, 105/420, Oxford July 2006, S. $443 \mathrm{ff}$.

10 Siehe unter anderem Robert Buijtenhuijs, Le FROLINAT et les guerres civiles du Tchad (19771984), Paris 1987, S. 108; Virginia Thompson / Richard Adloff, Conflict in Chad, Berkeley 1981, S. 116.

Khalid Y. Khalafalla, Der Konflikt in Darfur, APuZ, Bonn 4/2005, S. 40 ff.; Douglas H. Johnson, The Root Causes of Sudan's Civil Wars, Oxford 2004, S. 139 f.

12

In Darfur ist die Bevölkerung islamisch geprägt. Während in einigen Regionen lokale Sprachen gepflegt werden, ist Arabisch dort in jedem Falle lingua franca.

13

Alex de Waal, Who are the Darfurians?, a.a.O. (Fn. 6), S. 197. 
den in den 70er Jahren, erheblich verstärkte. ${ }^{14}$ Traditionelle Schlichtungsmechanismen vermochten diese immer weniger aufzufangen. ${ }^{15}$ Vielmehr wurden die Volksstämme, welche sich primär über den lokalen Kontext definierten, zunehmend in die militante, ethnopolitische Auseinandersetzung größerer Komplexität zwischen Tripolis, N'Djamena und Khartum verwickelt, bei der sie in einer als (pan-)arabisch ('arab) oder schwarz-(zuruq- ${ }^{16}$ ) afrikanisch propagierten Dichotomie sprichwörtlich „Farbe bekennen mussten“. ${ }^{17}$

\section{Die interne Dimension im sudanesischen Kontext}

Die Marginalisierung Darfurs führte schon früh zu Gruppierungen, die sich, in vielfältigen Akzentuierungen, dagegen auflehnten. So opponierten beispielsweise die al-lahìb al'aḥmar-Bewegung oder eine Gruppierung aus der Region am Ğabal Marra, die sog. șüniyy, gegen die Zentraleliten. Nach dem Sturz des unter Mängastu Haylä Maryam stehenden Därg-Regimes 1991 in Äthiopien durch die Tigrayan People's Liberation Front bzw. Hazbawi wäyyanä harannät Tagray (TPLF) und die Eritrean People's Liberation Front bzw. Hazbawi gənbar harannät Ertəra (EPLF) geriet Darfur verstärkt in den strategischen Fokus der südsudanesischen Sudan's People's Liberation Army (SPLA). Ihr Führer, Garang de Mabior, verlor durch den Sturz wichtigen Rückhalt in seinem Machtkampf sowohl in den eigenen Reihen gegen die neo-sezessionistischen Strömungen, ${ }^{18}$ als auch in der Konfrontation mit der GoS, was ihn dazu bewegte in Süd-Darfur neue Verbündete für seine unionistische Vorstellung eines New Sudan zu suchen. ${ }^{19}$ Die Einbeziehung Darfurs in den zweiten sudanesischen Nord-Süd-Bürgerkrieg (1983-2005) trug weiter dazu bei, dass sich die Gewaltspirale zwischen den Fronten in der Großregion Darfur schneller und ungezügelter drehte.

Douglas H. Johnson, a.a.O. (Fn. 11), S. 139; Gérard Prunier, a.a.O. (Fn. 6), S. 47; Khalid Y. Khalafalla, a.a.O. (Fn. 11), S. 40 ff.; Atta El-Battahani, a.a.O. (Fn. 3), S. 19; Alex de Waal, Briefing Darfur, Sudan: Prospects for Peace, African Affairs 104/414, Oxford Januar 2005, S. 127; Marina Peter, a.a.O. (Fn. 1), S. 16.

Vgl. dazu auch Atta El-Battahani, a.a.O. (Fn. 3), S. 19 (Aufzählungspunkt 12).

Diese Beschreibung (Pluralform von 'azraq = 'dunkel'-blau) wird im Sudan zur Bezeichnung von ,Schwarzafrikanern“ in einem pejorativen Sinne verwendet.

Es versteht sich von selbst, dass in einer außerordentlich heterogen besiedelten Region wie Darfur eine derart holzschnittartige Klassifikation der eigentlichen Komplexität nicht gerecht wird. Dennoch wird dieses plakative Raster in der Medienberichterstattung verwendet. Selbst in der wissenschaftlichen Auseinandersetzung bedient sich nach wie vor eine Vielzahl von Autoren der akademisch unzureichenden, unreflektierten Begründungsmuster.

Gérard Prunier, a.a.O. (Fn. 6), S. 72; ausführlich zu den Gegebenheiten innerhalb der SPLM/A Douglas H. Johnson, a.a.O. (Fn. 11), S. 91 f. (Kapitel 7).

19

Mängəstu Haylä Maryam favorisierte, selbst Verfechter der Unabhängigkeit des 1962 annektierten Eritreas, ein unionistisch revolutionäres Modell für den Sudan. Ausführlicher Kathrin Eikenberg, Der Eritrea Konflikt, in: Stefan Brüne / Volker Matthies [Hrsg.], Krisenregion Horn von Afrika, Hamburg 1990, S. 107-142. 


\section{Zur gegenwärtigen Konfliktlage in Darfur}

Noch vor dem militärischen coup d'état im Sudan im Jahre 1989 förderte Premierminister Șādiq al-Mahdī die ersten Milizen, deren Mitglieder mehrheitlich aus den in Darfur lebenden Volksgruppen der arabophonen Baqqāra rekrutiert wurden, um gegen die in der südöstlich angrenzenden Region Bahr al-Ġazāl ansässigen, die SPLA dominierende Volksgruppe der Dinkas ${ }^{20}$ vorzugehen.

\section{Die Protagonisten der bewaffneten Eskalation}

a) Ğann $\breve{g} \bar{a} w \bar{\imath} d$

Diese auch als murāhilīn bezeichneten Reitermilizen ${ }^{21}$ wurden trotz der alarmierenden Situation in Darfur von der GoS auch in jüngster Vergangenheit nicht entwaffnet. Im Gegenteil, die in Süd-Darfur beheimateten Baqqāra, die Rizayqāt konnten mit ihrer Bewaffnung Land- und Wasserkonflikte mit ihren nördlichen Nachbarn in Darfur für sich entscheiden. Sie sollen ferner sogar größtenteils unter Anleitung des sudanesischen Militärs ausgebildet worden sein. ${ }^{22}$ Gemeinsam mit anderen, sich ebenso als „arabischstämmig“ definierenden, gewaltbereiten Stämmen, welche sich ursprünglich auch als fursān oder muğähidīn bezeichneten, bilden sie die sogenannten $\breve{G} a n n \bar{g} \bar{a} w \bar{\imath} d .^{23}$ Diese sind strukturell als ein nicht kohärentes Gebilde zu verstehen. Sie formieren nach Thomas Schmidinger „quasi-staatliche Todesschwadronen staatlich sanktionierter Warlords, die zugleich ihre eigenen Interessen verfolgen und insofern nie vollständig vom Staat kontrolliert werden können“. ${ }^{24}$

\section{b) Die SLM}

Dieser Entwicklung und der staatlichen Repression stellten sich in Darfur Ende 2002/Anfang 2003 einige Gruppierungen entgegen. So wurde am 26. Februar 2003 die Darfur Liberation Movement gegründet. Ziel der Bewegung ist der Sturz der GoS und die Beendigung der Unterentwicklung und Vernachlässigung Darfurs. Wegen der gesamtsudanesischen Zielsetzung nannte sie sich am 14. März 2003 anlässlich der Verabschiedung

Zur genaueren Unterteilung und geographischen Verteilung der Dinkas im Sudan siehe Barbara F. Grimes (Hrsg.), Ethnologue, Volume I, Languages of the World, 14. Auflage, Dallas 2000, S. 220; dies., Ethnologue, Volume II, Maps and Indexes, 14. Auflage, Dallas 2000, S. 53.

Dieser Begriff wurde traditionell zur Bezeichnung junger Baqqāra-Männer verwendet, die ihr Vieh zu Pferde begleiteten. Ferner wurde er im Lauf der Zeit aber auch kategorisch zur Bezeichnung der, primär durch die Baqqāra geprägten, o.g. Milizen ausgeweitet. Vgl. u.a. Olaf Köndgen, Tragödie in Darfur, KAS-AI, Bonn 2004/10, S. 4 ff; Vgl. an dieser Stelle auch Farah Arbab, Dafur: The Fight for Peace, Strategic Studies, 24 (2004/4), S. 144, 149. 
ihrer politischen Charta in Sudan Liberation Movement bzw. Harakat li-tahrīr as-sūdān (SLM) um. ${ }^{25}$

\section{c) Die SFDA}

Neben dem militärischen Arm der SLM, der Sudan Liberation Army (SLA), traten noch weitere Guerillabewegungen auf. Die gleichfalls überwiegend aus Fūr gebildete Sudan Federalist Democratic Alliance bzw. at-taḥāluf al-fídirāliyy as-sūdāniyy ad-dīmūqrātịyy (SFDA) operiert allerdings weit gehend regional beschränkt, besonders im Ğabal Marra, und kämpft für die Rechte der Fūr und die Entwicklung Darfurs.

\section{d) Die SJEM}

Die hauptsächlich aus der erwähnten Volksgruppe der Zağāwa rekrutierte Sudan Justice and Equality Movement bzw. Harakat al-`adl wa-l-musāwāt as-sūdāniyya (SJEM, auch JEM) versteht sich im Vergleich zur stärker militärisch ausgerichteten SLA und SFDA eher als Vorläufer einer politischen Partei. Sie stellt ihren Kampf in einen größeren politischen Kontext, nämlich den des „Kampfes der marginalisierten Mehrheit“ sowohl gegen die Hegemonie der drei nordsudanesischen Ethnieen $\breve{S} \bar{a} y q i y y a, ~ G \breve{a} a^{c} l i y y \bar{i}$, und Danāqla, als auch gegen die damit einhergehende vernachlässigte Entwicklung ihrer Regionen. ${ }^{26}$

Gemeinsam ist den hier vorgestellten oppositionellen Gruppen in Darfur, dass sie von der politischen Konzeption her Unionisten sind. Sie streben, im Sinne einer offensiv inneren Ausprägung des Selbstbestimmungsrechts der Völker, nicht nach Unabhängigkeit für ihre Region (Darfur) ${ }^{27}$, also nicht nach dem ius secessionis ${ }^{28}$, sondern plädieren vielmehr wenn auch in unterschiedlichen Akzentuierungen - ähnlich wie der programmatische An-

Hanspeter Mattes, Sudan Sommer 2004: Frieden im Süden, Krieg im Westen, Konflikt mit der Opposition, Nord-Süd aktuell, Hamburg 2/2004, S. 276, 289.

26

Grundlage der entsprechenden Argumentation und Forderungen sind die im Sudan sog. kutub alÿaswad (Schwarzbücher), welche in zwei Teilen im Jahre 2000 und 2003 veröffentlicht wurden und unter Zuhilfenahme zahlreicher Statistiken die Doktrin der Hegemonie der nordsudanesischen Zentralelite nachweist. Der erste Teil (al-kitāb al-'aswad ğuz' al-'awwal) kann im Internet nachgelesen werden unter www.sudanjem.com/sudan-alt/arabic/books/black_book/black_book_ first/kitab.htm, der zweite Teil hiervon (al-kitāb al-’aswad ĝuz' at-tāniyy) unter www.sudanjem. com/sudan-alt/arabic/books/black_book/black_book_second/kitabaswad2.htm [zuletzt aufgerufen am 1. Januar 2007].

Das Selbstbestimmungsrecht der Völker stellt einen materiellen Grundpfeiler der modernen Völkerrechtsordnung dar. Es findet sich ausdrücklich erwähnt in Art. 1 Nr. 2, 55 UN-Charta und in der Dekolonialisierungsdeklaration von 1960, in der Friendly Relations-Deklaration von 1970, der Aggressionsdefinition von 1974 sowie in Art. 20 (1) der African [Banjul] Charter on Human and People's Rights von 1981. Implizit liegt es ferner den Regelungen der Kapitel XI - XIII der Charta der Vereinten Nationen zugrunde. gen 2000, S. $285 \mathrm{ff}$. 
satz der SPLM, für einen „New Sudan “29 auf Grundlage einer dezentralisierten Staatsstruktur, in der die Volksgruppen jeweils ihr defensiv inneres Selbstbestimmungsrecht ${ }^{30}$ bewahren können. ${ }^{31}$

e) Die GoS

Auf die prekäre Lage und auf Angriffe der oppositionellen Bewegungen auf staatliche Einrichtungen $^{32}$ reagierte die GoS mit ,harter Hand“. Die Krise sollte mit militärischen Mitteln nach dem Mandat des Artikels 122 der sudanesischen Verfassung durch die national konventionellen Streitkräfte, den quwwāt $a \check{s}-\check{s} a^{c} b$ al-musallaha, rasch beendet werden. Dies schloss nach Artikel 6 des Popular Defence Forces Act von 1989 die Unterstützung der paramilitärischen Popular Defence Force (PDF) mit ein. Eine Entwaffnung der an der Eskalation maßgeblich beteiligten $\breve{G}$ annğ $\bar{a} w \bar{l} d$ unterblieb. Ihnen wurde weiterhin weitgehend ,freie Hand“ gewährt, wobei teilweise sogar die personelle Differenzierung zwischen ihnen und der staatlich finanzierten $P D F$ verschwamm und operativ ineinander überging. ${ }^{33}$

\section{Faktische Realität und politische Pragmatik}

Die verheerenden Gewaltmaßnahmen der maßgeblich beteiligten Konfliktparteien, deren Splitterfraktionen sowie weiterer kleinerer, regional operierender Rebellenbewegungen, wurden immer ungezügelter auf dem Rücken der Zivilbevölkerung ausgetragen. Diese hatten vermehrt Massenexekutionen, Vergewaltigungen sowie Vertreibungen zur Folge und

29

30

Vgl. an dieser Stelle Hanspeter Mattes, a.a.O. (Fn. 25), S. 289.

Hinsichtlich der Wirkungsrichtung kann das Selbstbestimmungsrecht in eine innere und eine äußere Komponente aufgeteilt werden. Bezüglich der Art der Ausübung unterscheidet man innerhalb dieser Komponenten zwischen offensivem und defensivem Selbstbestimmungsrecht. Zum inneren Selbstbestimmungsrecht gehört demnach, dass ein Volk, welches nach Bildung eines Staates zu einem Staatsvolk wurde, frei über seine Regierungsform bestimmen kann. Dazu gehört aber auch, dass ethnische Minderheiten ihre Eigenarten bewahren und verteidigen können. Diesem defensiv inneren Charakter steht die offensiv innere Ausprägung der Selbstbestimmung unmittelbar gegenüber. Typisch dafür wäre beispielsweise die Sezession einer Minderheitengruppe aus dem bestehenden Staatenverbund. Hierzu Dietrich Murswiek, Offensives und defensives Selbstbestimmungsrecht, Der Staat, Berlin 1984, S. 523.

31

Zur sudanesischen Entwicklung im regional rechtsvergleichenden Kontext siehe Hatem Elliesie, Quo Vadis bilād as-Sūdān? The Contemporary Framework for a National Interim Constitution, Recht in Afrika (RiA), Köln 2005/1, S. 63 ff., insb. S. 71 ff.

32

Zu den einzelnen Geschehnissen siehe Kurt Beck, Die Massaker in Darfur, Zeitschrift für Genozidforschung, 5 (2004/2), S. 52, 54. Siehe auch Manjoj Kumar Sinha, Crisis in Darfur: International Response, Indian Journal of International Law, 45 (2005/3), S. 389, 390.

33

International Commission of Inquiry on Darfur, Report of the International Commission of Inquiry on Darfur to the United Nations Secretary-General, Genf 2005, S. 32 f. Im Internet nachzulesen unter http://www.ohchr.org/english/docs/darfurreport.doc [zuletzt aufgerufen am 20. Januar 2007]. So im Übrigen auch Kurt Beck, Die Massaker in Darfur, Zeitschrift für Genozidforschung, 5 (2004/2), S. 52, 56 bereits im Jahre 2004. 
hinderte die Flüchtlinge an der Rückkehr, insbesondere durch Abbrennen und Zerstörung von Dörfern. ${ }^{34}$ Die sudanesische Regierung behinderte zudem über viele Monate hinweg massiv humanitäre Hilfslieferungen nach Darfur oder machte sie ganz unmöglich. Wie viele Menschen bislang infolge des Darfur-Konflikts ums Leben gekommen sind, ist unklar. Die International Crisis Group geht von mindestens 200.000 Toten aus. ${ }^{35}$ Zudem wird geschätzt, dass rund 1,8 Millionen aus ihren Heimatdörfern vertriebene Menschen in Lagern innerhalb Darfurs oder in anderen Teilen des Sudans leben. Zwischenzeitlich dürften mehr als 200.000 Flüchtlinge aus Darfur im Tschad Zuflucht gefunden haben. ${ }^{36}$

Die jüngsten Eskalationen der schon lange existierenden Konflikte in Darfur sind in jedem Falle in direktem Zusammenhang mit dem Friedensprozess der GoA und der SPLM zu sehen. ${ }^{37}$ Die bilateral ausgestalteten Gespräche ${ }^{38}$ mögen verhandlungstechnisch sinnvoll gewesen sein, führten letztlich aber dazu, dass die SPLM ihre frühere Vision eines politisch umfassend transformierten New Sudan spätestens mit den Naivasha Protokollen ${ }^{39}$ faktisch fallen ließ. Daraus resultierte eine doppelte Exklusion; ausgeklammert wurden erstens die übrigen politischen, zivilgesellschaftlichen und militärischen Akteure des Landes und zweitens vornehmlich die westlichen und östlichen Regionen. Es verwundert daher nicht, dass übergangene regionale Akteure dadurch ermutigt wurden, ihre Forderungen ebenfalls gewaltsam zu artikulieren. Die internationalen Konfliktvermittler dagegen hofften, dass die Naivasha Protokolle als Katalysator für eine Lösung des Darfur-Konflikts wirken würden.

34

35

Siehe International Commission of Inquiry on Darfur, a.a.O. (Fn. 33), S. 3 f.

International Crisis Group, A New Sudan Action Plan, Africa Report N ${ }^{\circ} 24$, Nairobi/Brüssel, April 2005, S. 2.

Vgl. UNHCR Evaluation and Policy Analysis Unit, Real Time Evaluation of UNHR's Response to the Emergency in Chad, Genf 2004, S. 3; UNHCR, Global Appeal 2006, Genf 2005, S. 117, 122.

Manfred Öhm, Nach dem Frieden - mitten im Krieg: Der Sudan und der Dafurkonflikt, IPG, Bonn 2005/2, S. 150, 159.

Dazu Hatem Elliesie, Quo Vadis bilād as-Sūdān? The Contemporary Framework for a National Interim Constitution, Recht in Afrika (RiA), Köln 2005/1, S. 63, 65 f.; ausführlicher ders., a.a.O. (Fn. 31), S. 276 f.

Aufbauend auf dem Machakos Protocol, begannen im September 2003 weitere Verhandlungen zwischen der GoS und SPLM/A im kenianischen Naivasha. Dabei wurden zunächst Teilabkommen zu Sicherheitsfragen am 25.8.2003 und ein Abkommen zur Aufteilung der staatlichen Ressourcen sowie der Staatseinkünfte, das Wealth Sharing Agreement vom 7.1.2004, unterzeichnet. Weitere wichtige Teilabkommen wurden am 26.5.2004 zur Verteilung der politischen Macht, das Power Sharing Agreement, sowie zum Status der Gebiete der Southern Kordofan/Nubaberge, Southern Blue Nile und Abyei unterzeichnet. Alle diese Vereinbarungen werden auch als die „Naivasha Protokolle“ bezeichnet. Näher beleuchtet durch Hatem Elliesie, Friedensprozess und Verfassungsentwicklung im Sudan, a.a.O. (Fn. 31), S. 283 ff. 
Zum Jahresende 2004 kam es hingegen in Darfur zu einer weiteren Eskalation des Konflikts und zur Verschärfung der humanitären Krise. ${ }^{40}$

\section{Der Sudan, das Völkerrecht und die Rolle der UN}

\section{Der Sudan und die Internationale Gemeinschaft}

\section{Sudan im Menschenrechtsschutzsystem der UN}

Richtet man sein Augenmerk aus dem Blickwinkel der desaströsen Situation in Darfur im Speziellen und des jahrzehntelangen Bürgerkriegs im Sudan im Allgemeinen auf das Menschenrechtssystem der Vereinten Nationen (UN), so erscheint ein Hinweis auf die Bindung des Sudans an die relevanten völkerrechtlichen Verträge bemerkenswert: Der Sudan ist hierin unter anderem an den International Covenant on Civil and Political Rights $\left(\mathrm{CCPR}^{41}\right)$, die International Convention on the Elimination of All Forms of Racial Discrimination $\left(\mathrm{CERD}^{42}\right)$, aber auch an die Convention on the Rights of the Child $\left(\mathrm{CRC}^{43}\right)$, das Optional Protocol to the Convention on the Rights of the Child on the Involvement of Children in Armed Conflict (OP-CRC-AC ${ }^{44}$ ), die Convention on the Prevention and Punishment of the Crime of Genocide ${ }^{45}$ sowie zusätzlich an die vier Genfer Konventio${ }^{4}{ }^{46}$ als wichtige Komponente des humanitären Völkerrechts gebunden. Die Verpflichtung zur Einhaltung der eingegangenen Völkerrechtsbindung sollte für sich gesehen eigentlich schon eine Selbstverständlichkeit darstellen. Es gilt der Grundsatz der Vertragstreue (pacta sunt servanda), widergespiegelt in der Wiener Vertragsrechtskonvention, einschließlich der Nichtberufbarkeit auf innerstaatliches Recht zwecks Rechtfertigung der Nichterfüllung gemäß Artikel 26 und 27. Auf die Grundverpflichtung pacta sunt servanda wird im gemeinsamen Artikel 1 der Genfer Konvention explizit und in gesteigerter Form hingewiesen, indem die Genfer Konventionen ,unter allen Umständen einzuhalten und

Denis M. Tull, Der Sudan nach dem Naivasha-Friedensvertrag - Noch kein Anlaß zur Euphorie, SWP-Aktuell 2005/01, Berlin 2005, S. 4 f.

Akzession Sudans im Jahre 1986.

Akzession Sudans im Jahre 1977.

Ratifikation Sudans im Jahre 1990.

Ratifikation Sudans im Juli 2005.

Akzession Sudans im Jahre 2003.

Die Bestimmungen der vier Konventionen von 1949 betreffen die Verwundeten und Kranken der Streitkräfte im Felde (Genfer Abkommen I), die Verwundeten, Kranken und Schiffbrüchigen der Streitkräfte zur See (Genfer Abkommen II), die Behandlung der Kriegsgefangenen (Genfer Abkommen III) und den Schutz von Zivilpersonen in Kriegszeiten (Genfer Abkommen IV). 
durchzusetzen“ sind. ${ }^{47}$ Dementsprechend, sowie speziell für interne Konflikte konzipiert, bildet der gemeinsame Artikel 3 der Genfer Konventionen von $1949^{48}$ den Kern des humanitären Völkerrechts. ${ }^{49}$ Diese Regelung stellt unabdingbares, zwingendes Völkerrecht dar, nicht nur in ihrer Eigenschaft als Völkervertragsrecht, sondern ebenso als Ausdruck von Völkergewohnheitsrecht ${ }^{50}$ und ist folglich für alle Staaten bindend. ${ }^{51}$ Diese gewohn-

Manfred Mohr, Durchsetzungsmechanismen des humanitären Völkerrechts - eine aktuelle Bestandsaufnahme, in: Jana Hasse / Erwin Müller / Patricia Schneider [Hrsg.], Humanitäres Völkerrecht. Politische, rechtliche und strafgerichtliche Dimension, Baden-Baden 2001, S. 158, $163 \mathrm{f}$.

Gemeinsamer Artikel 3 der Genfer Konvention von 1949:

In the case of armed conflict not of an international character occurring in the territory of one of the High Contracting Parties, each Party to the conflict shall be bound to apply, as a minimum, the following provisions:

(1) Persons taking no active part in the hostilities, including members of armed forces who have laid down their arms and those placed hors de combat by sickness, wounds, detention, or any other cause, shall in all circumstances be treated humanely, without any adverse distinction founded on race, colour, religion or faith, sex, birth or wealth, or any other similar criteria.

To this end, the following acts are and shall remain prohibited at any time and in any place whatsoever with respect to the above-mentioned persons:

(a) violence to life and person, in particular murder of all kinds, mutilation, cruel treatment and torture;

(b) taking of hostages;

(c) outrages upon personal dignity, in particular humiliating and degrading treatment;

(d) the passing of sentences and the carrying out of executions without previous judgement pronounced by a regularly constituted court, affording all the judicial guarantees which are recognized as indispensable by civilized peoples.

(2) The wounded and sick shall be collected and cared for.

An impartial humanitarian body, such as the International Committee of the Red Cross, may offer its services to the Parties to the conflict.

The Parties to the conflict should further endeavour to bring into force, by means of special agreements, all or part of the other provisions of the present Convention.

The application of the preceding provisions shall not affect the legal status of the Parties to the conflict.

Lutz Lehmler, Die Strafbarkeit von Vertreibungen aus ethnischen Gründen im bewaffneten nichtinternationalen Konflikt: Zugleich ein Beitrag zur neueren Entwicklung des Völkerstrafrechts, Baden-Baden 1999, S. 266; Christopher Greenwood, Anwendungsbereich des humanitären Völkerrechts, in: Dieter Fleck [Hrsg.], Handbuch des humanitären Völkerrechts in bewaffneten Konflikten, München 1994, S. 34 (41/211).

Vgl. Theodor Meron, War Crimes in Yugoslavia and the Development of International Law, American Journal of International Law (AJIL), Washington D.C. 1994, S. 78, 80; Christopher Greenwood, Customary Law Status of the 1977 Geneva Protocol, in: Astrid J.M. Delissen / Gerald J. Tanja [Hrsg.], Humanitarian Law of Armed Conflict, Challenges Ahead, Essays in Honour of Fits Kalshoven, Dodrecht / Boston / London 1991, S. 93, 98.

Dazu Lutz Lehmler, a.a.O. (Fn. 49), S. 266; Hans-Peter Gasser, Armed Conflict within the Territory of a State, in: Walter Haller / Alfred Kölz / Georg Müller / Daniel Thürer [Hrsg.], Im Dienst an der Gemeinschaft (Festschrift für Dietrich Schindler zum 65. Geburtstag), Basel / Frankfurt a. 
heitsrechtliche Geltung des gemeinsamen Artikel 3 der Genfer Konvention von 1949 wurde auch vom International Criminal Tribunal for the former Yugoslavia (ICTY) bei seiner Tadić-Entscheidung vom 2. Oktober 1995, unter Berufung auf die Entscheidung La República de Nicaragua vs. United States of America des International Court of Justice (ICJ) vom 27. Juni 1986, bestätigt. ${ }^{52}$

Trotz der massiven grenzüberschreitenden Flüchtlingsströme, welche auch Auswirkungen auf die soziale, wirtschaftliche oder interne Stabilität einiger Nachbarstaaten hat, ${ }^{53}$ weist der bewaffnete (Darfur-)Konflikt einen nicht internationalen Charakter ${ }^{54}$ auf. ${ }^{55}$ Demgemäß ist dem Sudan untersagt, vor allem Angriffe auf Leib und Leben sowie die Beeinträchtigung der Würde durch erniedrigende und entwürdigende Behandlung der Zivilbevölkerung zu dulden. Außerdem hat sich die sudanesische Regierung in Chapter II (Power Sharing Agreement) des CPA in 1.6.1 Satz 1 erneut eindeutig und ausdrücklich dazu bekannt, dass "the Republic of Sudan, including all levels of government throughout the country, shall comply fully with its obligations under the international human rights treaties to which it is or becomes a party”. Bisher hat der Sudan allerdings das erste und zweite Zusatzprotokoll der Genfer Konvention ebenso wenig ratifiziert wie das Statut des Internationalen Strafgerichtshofs (IStGH). Letzteres wurde jedoch am 8. September 2000 unterzeichnet, ${ }^{56}$ was zumindest impliziert, dass der Sudan insoweit daran gebunden ist, als er die Zielsetzung und Zweckbestimmung des Gerichts nicht vereitelt. ${ }^{57}$

M. 1989, S. 225, 227. Dies bestätigte zudem der IGH in seinem Urteil vom 27. Juni 1986 in dem Rechtsstreit Nicaraguas gegen die Vereinigten Staaten von Amerika, ICJ Reports 1986, S. 114.

52

53

54

ICJ Reports 1986, S. 114.

Man denke an die riesigen Flüchtlingslager sudanesischer Flüchtlinge im Tschad.

Siehe zum Begriff des "nicht-internationalen Konflikts" im Sinne des gemeinsamen Artikel 3 der Genfer Konvention von 1949 vor allem Commission of Experts, Preliminary Report of the Independent Commission established in accordance with Security Council Resolution 935 (1994), UN-Doc. S/1994/1125 Annex, New York 4. Oktober 1994, S. 20, para. 91; ders., Final Report of the Commission of Experts established pursuant to Security Council Resolution 935 (1994), UNDoc. S/1994/1405 Annex, New York 9. Dezember 1994, S. 22, para. 108 f.

So auch Yolanda Gamarra / Alejandra Vicente, Securing Protection to Civilian Population : The Doubtful United Nations Response in Sudan, The Global Community Yearbook of International Law \& Jurisprudence, Dobbs Ferry 2004, 4 (I), S. 195, 200. Christopher Greenwood liefert in Dieter Fleck [Hrsg.], a.a.O. (Fn. 49), 41/210 f., eine für Darfur zutreffende Definition: „Ein nichtinternational bewaffneter Konflikt ist eine mit Waffengewalt innerhalb eines Staatsgebietes ausgetragene Auseinandersetzung zwischen der bestehenden Staatsgewalt und dieser Staatsgewalt unterworfenen Personengruppen, welche die Größenordnung eines bewaffneten Aufruhrs oder Bürgerkrieges erreicht".

International Commission of Inquiry on Darfur, a.a.O (Fn. 33), S. 148 (para. 583).

Yolanda Gamarra / Alejandra Vicente, a.a.O. (Fn. 55), S. 200. So auch Noha Ibrahim, Simone Malz / Verena Wiesner [Hrsg.], Max-Planck Compilation of International Human Rights Treaties - Sudan, Heidelberg 2005, S. 5. Auch im Internet unter www.mpil.de/shared/data/pdf/ 


\section{Die humanitäre, völkerrechtliche Verpflichtung des Sudans und die UN}

Insgesamt ist unbestritten, dass alle Regierungen der Staatengemeinschaft die Verantwortung haben, ihre Zivilbevölkerung zu beschützen. Sie haben den Schutz der Zivilbevölkerung sicherzustellen und Angriffe ungeachtet dessen zu vermeiden, ob die Täter unter der Kontrolle der Regierung stehen oder nicht. Ein Mindeststandard an humanitärer staatlicher Verpflichtung und ein nicht reduzierbarer Kern von Menschenrechten muss dementsprechend allerorts und zu jeder Zeit bestehen bleiben. ${ }^{58}$ Auch entzieht die Anwesenheit von Nicht-Zivilisten in Dörfern oder Gebieten einer bewaffneten Auseinandersetzung der Bevölkerung nicht deren zivilistischen Status. ${ }^{59}$ Falls eine Regierung nicht in der Lage ist, Zivilpersonen selbst zu schützen, soll sie die Internationale Gemeinschaft um humanitäre Unterstützung ersuchen. Demnach liegt die Verantwortung zur Beendigung von Angriffen auf Zivilisten, zusätzlich zur Verpflichtung, die Zivilbevölkerung zu beschützen, bei der sudanesischen Regierung. ${ }^{60}$ Selbst wenn also Rebellen in einem Dorf oder Gebiet anwesend waren oder diese die Zivilbevölkerung als „Schutzschild“ nutzten, würde dies letztlich

international_human_rights_treaties_-_sudan_english.pdf nachlesbar [Zuletzt aufgerufen am 20. Januar 2007].

Theodor Meron, The Protection of the Human Person under Human Rights Law and Humanitarian Law, Genf 1992, Bulletin of Human Rights 45 (1992). Vgl. auch den für den Sudan bindenden gemeinsamen Artikel 3 zu den vier Genfer Konventionen von 1949 (Fn. 48). Siehe ferner hierzu insbesondere das obiter dictum des Internationalen Gerichtshofes (IGH) im Barcelona Traction, Light and Power Company, Limited-Fall (Belgien gegen Spanien), Zweite Phase, Urteil vom 5. Februar 1970, ICJ Reports, 1970, S. 32, wonach, an essential distinction should be drawn between the obligations of a State towards the international community as a whole, and those arising vis-à-vis another State in the field of diplomatic protection. By their very nature the former are the concern of all States. In view of the importance of the rights involved, all states can be held to have a legal interest in their protection; they are obligations erga omnes. Such obligations derive, for example, in contemporary international law, from the outlawing of [...] genocide, as also from the principles and rules concerning the basic rights of the human person, including protection from slavery and racial discrimination. Some of the corresponding rights of protection have entered into the body of general international law [...]; others are conferred by international instruments of a universal or quasi-universal character".

UN, International Criminal Tribunal for Rwanda (ICTR), Trial Chamber, Entscheidung vom 2. September 1998, The Prosecutor v. Jean-Paul Akayesu (Case No. ICTR-96-4-T), para. 582: "Where there are certain individuals within the civilian population who do not come within the definition of civilians, this does not deprive the population of its civilian character." Siehe auch ICTR, Entscheidung vom 6. Dezember 1999, The Prosecutor v. Georges Anderson Nderubumwe Rutaganda (Case No. ICTR-96-3), para. 72; ICTR, Entscheidung vom 27. Januar 2000, The Prosecutor v. Alfred Musema (Case No. ICTR-96-13-A), para. 207 sowie ICTR, Entscheidung vom 21, Mai 1999, The Prosecutor v. Clément Kayishema and Obed Ruzindana, (Case No. ICTR-951-T), para. 128: "The targeted population must be predominantly civilian in nature but the presence of certain non-civilians in their midst does not change the character of that population." Vgl. ebenso ICTR, Entscheidung vom 15. Mai 2003, The Prosecutor v. Laurent Semanza (Case No. ICTR-97-20-T), para. 330.

Yolanda Gamarra / Alejandra Vicente, a.a.O. (Fn. 55), S. 200. 
in keinem Falle Angriffe auf Leib und Leben von Zivilisten, die an den Kampfhandlungen nicht unmittelbar teilnehmen, rechtfertigen. ${ }^{61}$

\section{Ius Cogens: Verpflichtung aller sudanesischen Konfliktparteien}

Der gemeinsame Artikel 3 der Genfer Konventionen enthält aber nicht nur Rechte und Pflichten für die sudanesische Regierung. Schon aus dem Wortlaut ergibt sich nämlich, dass ,jede der am Konflikt beteiligten Parteien gehalten“ ist „mindestens die folgenden Bestimmungen anzuwenden“. Dies muss wegen der Zugehörigkeit des gemeinsamen Artikel 3 der Genfer Konventionen zum völkerrechtlichen ius cogens auch dann der Fall sein, wenn der Heimatstaat nicht Signatar der Genfer Konvention sein sollte. Ferner sind Individuen in der Ausführung von Kampfhandlungen in internationalen Kriegen immer an das Kriegsrecht gebunden. Im Zuge eines argumentum a maiore ad minus kann in einem solchen, ,nicht-internationalen Konflikt" daher nichts anderes gelten. ${ }^{62}$

\section{Die Internationale Gemeinschaft und die Ausgangssituation für die UN}

Die internationale Aufmerksamkeit konnte zum Zeitpunkt der Eskalation in Darfur 2003 nur äußerst langsam auf das nach Ruanda größte humanitäre Desaster auf dem afrikanischen Kontinent gelenkt werden. Zu sehr war man international mit den Ereignissen im Irak beschäftigt. Während internationale Medien langsam mit der Berichterstattung über die

Vergleiche dazu Artikel 6 Absatz 1 Satz 2 ICCPR sowie Artikel 4 Satz 3 der African [Banjul] Charter on Human and Peoples' Rights von 1981. Ferner UN-Menschenrechtsausschuss, General Comment No. 29, para. 11, UN-Doc. CCPRT/C/21/Rev.1/Add.11, Genf 2001, S. 4. Siehe aber auch schon UN-Generalversammlung, Resolution 2444 (XXIII), New York 19. Dezember 1968, wonach unter dem Titel 'Respect for Human Rights in Armed Conflicts', erste Richtlinien „für die gouvernmentale als auch andere Befehlsgewalten, welche für Taten in bewaffneten Konflikten verantwortlich sind" festgelegt wurden, unabhängig davon, ob diese als intern- oder internationalbewaffnete Konflikte einzustufen sind. Danach wurden folgende drei Prinzipien statuiert:

a) that the rights of the parties to a conflict to adopt means of injuring the enemy is not unlimited;

b) that it is prohibited to launch attacks against the civilians population as such;

c) that the distinction must be made at all times between persons taking part in the hostilities and members of the civilian population to the effect that the latter be spared as much as possible.

Weiterführend zu letzterem Hans-Peter Gasser, Armed Conflict within the Territory of a State, a.a.O. (Fn. 51), S. 230.

62 Dietrich Schindler, Different Types of Armed Conflicts according to the Geneva Conventions and Protocols, in: Haagse Academie voor Internationaal Recht / UN [Hrsg], Recueil des cours / Académie de Droit International de La Haye 1979 II, Den Haag u.a. 1980, S. 121, 151 f.; Lutz Lehmler, a.a.O. (Fn. 49), S. 37. Auch der ICJ hat dies in seinem oben zitierten Urteil (Fn. 51) vom 27. Juni 1986 bestätigt. 
Region begannen, hielt sich die Politik erstaunlich bedeckt, ebenso die UN. Der UNSicherheitsrat befand sich mitten in der Kontroverse, wie man nun der Invasion durch die 'multinationale Allianz' in den Irak begegnet. Ferner war die UN zutiefst in den NaivashaProzess involviert. Die Unterstützung in der Durchführung der IGAD-Verhandlungen und deren möglichst positiver Ausgang genossen gegenüber der sich zuspitzenden, überaus besorgniserregenden Gewaltbereitschaft im Westen des Sudans offensichtlich eine deutlich höhere Priorität. ${ }^{63}$ So war die Rolle der Internationalen Gemeinschaft, die Situation aufmerksam zu verfolgen und sich damit zu beschäftigen, auf die Initiative einiger weniger NGO's ${ }^{64}$ und sonstiger Institutionen ${ }^{65}$ beschränkt. Dies ermöglichte es der GoS Naivasha gewissermaßen gegen Darfur auszuspielen. ${ }^{66}$

\section{Der (undurchsichtige) Abéché-Prozess}

Die erste internationale politische Initiative, der sich zuspitzenden humanitären Krise zu begegnen, erfolgte aus diesem Grunde zunächst im Schatten der internationalen Aufmerksamkeit. So nutzte der tschadische Präsident Idriss Déby, selbst ein Angehöriger der Volksgruppe der Zajḡâwa, im Sommer 2003 einerseits seine persönlichen Kontakte zu hochrangigen Za $\dot{g} \bar{a} w a$ in der Führungsriege der SLM/A und andererseits seine verstrickten Kontakte nach Khartum, für mediatorische Gespräche in der grenznahen Stadt Abéché im Tschad. Die SJEM verweigerte hingegen die Teilnahme an diesen Vermittlungsgesprächen, da sie eine tschadische Mediation für parteiisch erachtete. Aus der ersten Verhandlungsrunde resultierte am 3. September 2003 ein Waffenstillstandsabkommen, ${ }^{67}$ das zwischen den Parteien gemäß Artikel 7 zum 6. September 2003 für 45 Tage in Kraft trat. Betrachtet man die Sicherheitsklausel des Artikel 7 genauer, so fällt sie zwar als die detaillierteste Regelung der neun Artikel umfassenden Vereinbarung auf, ist aber inhaltlich dennoch vage

Die International Crisis Group führte dazu an, dass "The international reaction to the crisis has been woefully inadequate. The IGAD peace talks have been prioritised at the cost of holding the government accountable for its actions in Darfur", siehe International Crisis Group, Dafur Rising: Sudan's New Crisis, Africa Report N76, Nairobi/Brüssel März 2004, S. 24.

Siehe in diesem Kontext u.a. den Appell von Amnesty International, Sudan: Urgent Call for Commission of Inquiry in Darfur as Situation Deteriorates, Internationale Presse Veröffentlichung, London 21. Februar 2003, AI-Index AFR 54/004/2003. Im Internet nachzulesen unter http://web.amnesty.org/library/index/engafr540042003 [zuletzt aufgerufen am 21. Januar 2007].

Einen guten Einblick in die innersudanesischen Geschehnisse seit Anfang 2003 gibt auch markaz. ad-dirāsāt as-sūdāniyya (Das Zentrum sudanesischer Studien), hālat al-wațan, Khartum / Kairo 2004, S. 238-257 sowie S. 189 ff. und S. 25 ff.

Gérard Prunier, a.a.O. (Fn. 6), S. 141 ; Yolanda Gamarra / Alejandra Vicente, a.a.O. (Fn. 55), S. 201; Hugo Slim, Dithering over Darfur? A Prelimary Review of the International Response, International Affairs, London 2004/5, S. 811, 814; Paul D. Williams / Alex J: Bellamy, The Responsibility to Protect and the Crisis in Darfur, Security Dialogue, 36 (2005/1), S. 27, 38. 
genug verfasst, um ausreichend Interpretationsspielraum für die widerstreitenden Grundpositionen zu gewähren. ${ }^{68}$ Dem Ansinnen der GoS, die Darfur-Krise als innere (Sicherheits-)Angelegenheit zu qualifizieren und damit zunächst keinen Spielraum für mögliche $U N$-Interventionen auf Grundlage des Artikel 2 Nr. 7 UN Charta zuzulassen, wurde in dieser Form eine Basis geschaffen. Weitere Verhandlungsrunden in Abéché vom 26. Oktober bis 4 . November desselben Jahres waren dementsprechend rasch festgefahren, als sich die Parteien gegenseitig des Verstoßes gegen die Waffenruhe beschuldigten und die SLM/A ihre substanzielle Mitwirkung von der Verabschiedung international überwachter Protokolle zum Schutze der Zivilisten sowie ungehinderten Zugangs von Hilfslieferungen in die unter ihrer Kontrolle stehenden Regionen abhängig machte. Das dürftige Ergebnis des Waffenstillstandsabkommens bestätigte sowohl die gegenläufigen Interpretationen der vereinbarten Anhänge zur Sicherheitsklausel als auch die umstrittene Frage, den AbéchéProzess zu internationalisieren. ${ }^{69}$ Die letzte Verhandlungsrunde kollabierte schließlich am 16. Dezember 2003. Der tschadische Innenminister berichtete der Presse, dass ,there has been a breakdown in negotiations because of unacceptable rebel demands. The talks have been suspended; it's a failure “. ${ }^{70}$ Tatsächlich aber fanden die veranschlagten Gespräche überhaupt nicht statt. Die GoS-Delegation verweigerte die Aufnahme der dritten Verhandlungsrunde, nachdem sie vorab von der Agenda der SLM erfuhr. ${ }^{71}$ Damit war die Initiative gescheitert und, viel schlimmer noch, das dringende Bedürfnis, die Ğannğg $\bar{a} w \bar{\imath} d$ zu entwaffnen, die Flüchtlingsströme zu bewältigen und die Eskalation zumindest in dem von der SLA kontrollierten Gebiet einzudämmen, missglückt.

\section{Die erste (offizielle) Resonanz der UN}

Mit den erneuten Offensiven der Regierung im Dezember 2003 wurde es zunehmend schwerer, die gewaltsame Vertreibung und die Gräueltaten zu ignorieren. UN-UnderSecretary-General for Humanitarian Affairs and Emergency Relief Coordinator Jan Egeland wies immer deutlicher auf die sich verschlechternde humanitäre Situation in Darfur

Dazu genauer International Crisis Group (ICG), Dafur Rising: Sudan's New Crisis, a.a.O. (Fn. 63), S. $21 \mathrm{f}$.

Siehe auch United Nations Office for the Coordination of Humanitarian Affairs, Integrated Regional Information Networks (IRIN), Sudan: Gov't, Darfur Rebels extended Ceasefire for one Month, Nairobi 5. November 2003.

Associated Press, "Sudan Government, Rebels Peace Talks break down in Chad", 16. Dezember 2003.

71 Gérard Prunier, a.a.O. (Fn. 6), S. 109; International Crisis Group (ICG), Dafur Rising: Sudan's New Crisis, a.a.O. (Fn. 63), S. 23. Zum umstritten Darfur Peace Agreement (DPA) nach insgesamt 7 Verhandlungsrunden in Abuja am 5. Mai 2006 siehe die kritische Abhandlung von Gérad Prunier, Fauler Frieden: Vom kläglichen Versagen der internationalen Gemeinschaft, Der Überblick, Heft 3, Hamburg (September) 2006, S. 26 ff; Manfred Öhm, Sudan: Politischer Übergang ohne Machtwechsel, FES (Friedrich-Ebert-Stiftung) Analyse, Khartum / Bonn (Juli) 2006, S. 11. 
hin und bezeichnete sie auf der 4877. Sitzung des UN-Sicherheitsrates als eine gravierende Angelegenheit, ${ }^{72}$ gar eine der schlimmsten der Welt. ${ }^{73}$ Alle, die in der Region über Kontrolle von Truppen und Gebieten verfügen, sollten nach internationalem Recht für die verloren gegangenen Leben (,,lives being lost") zur Verantwortung gezogen werden, weil die Hilfeleistung der United Nations Office for the Coordination of Humanitarian Affairs (OCHA) verhindert wurde. ${ }^{74}$ Forciert durch die etwa zeitgleiche offizielle UN-Visite in den drei westsudanesischen Provinzen durch Tom Eric Vraalsen, Secretary-General's Special Envoy for Humanitarian Affairs for Sudan, wurde zum Jahresende 2003 das internationale Schweigen gebrochen. ${ }^{75}$ Simultan ließ der Generalsekretär der Vereinten Nationen Kofi Annan seine Besorgnis über die Verschlechterung der humanitären Situation in der DarfurRegion verlauten und mahnte noch vor der ursprünglich veranschlagten letzten Verhandlungsrunde des Abéché-Prozesses zu dessen Vollendung. ${ }^{76}$ Ein humanitärer Waffenstillstand wurde zur diplomatischen Priorität der UN. Die Schwierigkeit bei diesem Vorstoß lag indes darin, dass er nicht mit einem politischen Prozess verknüpft war und daher längerfristig nicht aufrecht zu erhalten war. ${ }^{77}$ Außerdem baute er auf der Wiederaufnahme des Abéché-Prozesses auf, welcher seinerseits mit grundlegenden Makeln behaftet ist. ${ }^{78}$

\section{Rolle und Reaktion der maßgeblichen UN-Organe auf die Darfur-Krise}

Die Situation verlangte eine eindeutige Haltung und gezielte Maßnahmen der Weltgemeinschaft im Rahmen der Vereinten Nationen. Neben der politischen Prärogative des Sicherheitsrates der Vereinten Nationen ${ }^{79}$ im Bezug auf Kapitel VII der UN-Charta, war die zwischenzeitlich aufgrund der Schaffung des neuen Menschenrechtsrats aufgelöste Men-

Jan Egeland, Statement of the Under-Secretary-General Jan Egeland at the $4877^{\text {th }}$ Meeting of the Security Council on the Protection of Civilians in Armed Conflict, New York 9. Dezember 2003. Im Internet nachzulesen unter http://ochaonline.un.org/GetBin.asp?DocID=98 [zuletzt aufgerufen am 21. Januar 2007].

United Nations Office for the Coordination of Humanitarian Affairs, Integrated Regional Information Networks (IRIN), Sudan: UN Humanitarian Chief worried by Darfur Crisis, Nairobi 8. Dezember 2003.

Jan Egeland, Pressekonferenz, United Nations Office for the Coordination of Humanitarian Affairs, Genf 11. Dezember 2003.

United Nations Secretary General Kofi Annan, Secretary General alarmed by Deteriorating Humanitarian Situation in Darfur Region of Sudan, Press Release, New York 9. Dezember 2003, UN-Doc. SG/SM/9067, AFR/790. der Rolle eines Sonderberichterstatters, Vereinte Nationen, Baden-Baden 3/2002, S. 110, 115. 
schenrechtskommission $^{80}$ eines der politischsten Gremien der Vereinten Nationen zur Förderung und Durchsetzung der Menschenrechte. ${ }^{81}$

\section{Die Menschenrechtskommission der Vereinten Nationen}

Die UN-Menschenrechtskommission (United Nations Commission on Human Rights UNCHR) war eine gemäß Artikel 68 der UN-Charta eingesetzte Fachkommission der Vereinten Nationen zur Förderung und zum Schutz der völkerrechtlich verbindlichen Menschenrechte. Das Gremium wurde 1946 gegründet und war als Unterorgan dem UNWirtschafts- und Sozialrat rechenschaftspflichtig. Zur Lenkung des öffentlichen Interesses beurteilte sie die Lage der Menschenrechte in bestimmten Ländern. Dabei kam es innerhalb des Gremiums immer wieder zu Kontroversen über die Auswahl der Länder, in die die Sonderberichterstatter letztendlich entsendet werden. Den Kontrollkompetenzen der UNCHR waren allerdings Grenzen gesetzt, sie durfte Menschenrechtsverletzungen nur feststellen und öffentlich verurteilen. Entscheidungen über Maßnahmen zur Durchsetzung und Wahrung der Rechte wurden vom UN-Sicherheitsrat und/oder der UN-Generalversammlung getroffen. ${ }^{82}$

\section{a) Der Sonderberichterstatter der UNCHR für den Sudan}

Nach dem Rücktritt von Leonardo Franco wurde im Dezember 2000 der ehemalige deutsche Innenminister Gerhart Baum zum Sonderberichterstatter für den Sudan berufen. ${ }^{83}$ Sein Mandat wurde am 19. April 2002 durch die Resolution CHR 2002/16 mit knapper Mehrheit von $25 \mathrm{zu} 24$ Stimmen bei vier Enthaltungen um ein Jahr verlängert. ${ }^{84} \mathrm{Er}$ hatte seit seiner Ernennung den Sudan dreimal besucht. ${ }^{85}$ Waren sein Zwischenbericht $2001^{86}$ und

Vgl. UN-Doc. A/Res/60/251, 15. März 2006; UN-Doc. E/Res./2006/2, 22. März.2006 sowie UN Doc. E/CN.4/2006/L2, Nr. 4, 24. März 2006.

Gerhart R. Baum, Sudanesische Menschenrechtsbilanz, a.a.O. (Fn. 77) S. 111; Regina Bernhard / Hildegard Lingnau, Die Vereinten Nationen und die Darfur Krise: Nationale Interessen stehen einer Lösung im Wege, Vereinte Nationen, Baden-Baden 5/2004, S. 167 f.

Zur Darstellung der Arbeit der Menschenrechtskommission zwischen 1946 und 1992 siehe Philip Alston, The Commission on Human Rights, in: ders. [Hrsg.], The United Nations and Human Rights: A Critical Appraisal, Oxford 1992, S. 126-210.

Gerhart R. Baum, Sudanesische Menschenrechtsbilanz, a.a.O. (Fn. 77), S. 110.

Siehe dazu http://ap.ohchr.org/documents/E/CHR/resolutions/E-CN_4-RES-2002-16.doc [zuletzt aufgerufen am 21. Januar 2007].

März und Oktober 2001 sowie Februar/März 2002.

Gerhart Baum, Interim Report of the Special Rapporteur of the Commission on Human Rights on the Situation of Human Rights in the Sudan, UN-Doc. A/56/336, New York 7. September 2001. 
sein Bericht $2002^{87}$ naturgemäß noch stark durch den sudanesischen Nord-Süd-Konflikt geprägt, so verhallten seine Stellungnahmen und Berichte zum Darfur-Konflikt weitgehend ungehört. ${ }^{88}$ Just in dem Moment, als die Darfur-Krise auf ihren fürchterlichen Höhepunkt zusteuerte, lief jedoch sein Mandat aus und wurde nicht erneuert. ${ }^{89}$

\section{b) Evaluation der UNCHR (in der Darfur-Krise)}

Im Rahmen der Sitzungen der UNCHR gelang es überdies nicht, den Sudan angemessen kritisch anzugehen. Es gelang nicht einmal eine Mehrheit für eine von der Europäischen Union initiierte Resolution zu finden, in der die sudanesische Regierung wegen der Menschenrechtsverletzungen und Verstöße gegen das Völkerrecht ${ }^{90}$ in Darfur scharf kritisiert wurde. Stattdessen wurde am 23. April 2004 eine sehr viel schwächer formulierte Erklärung verabschiedet, ${ }^{91}$ die ohnehin keinen bindenden, sondern lediglich deklaratorischen Charakter hat. Ferner wurde am 4. Mai 2004 der Sudan sogar wieder in die UN-Menschenrechtskommission aufgenommen.

aa) Generell lässt sich feststellen, dass die UN-Menschenrechtskommission zwar das einzige weltweite Forum zur Aussprache der Menschenrechtslage war, denn allein die Existenz, die Debatten und Beschlüsse stärkten den Menschenrechtsschutz und brachten die Täter in die Defensive. Sie hatte eine nicht zu unterschätzende moralische Autorität. Ihr Defizit bestand allerdings im Verfahren ${ }^{93}$ und der mangelnden Öffentlichkeit, genauer im mangelnden öffentlichen Interesse. Dies verdeutlicht die Darfur-Krise augenscheinlich. Der Nahe Osten band nahezu die gesamte Aufmerksamkeit.

Gerhart Baum, Report of the Special Rapporteur, Gerhart Baum, submitted in accordance with Commission Resolution 2001/18 on the Situation of Human Rights in the Sudan, UN-Doc. E/CN.4/2002/46, New York 23. Januar 2002.

Siehe u.a. Gerhart Baum, Statement by Mr. Gerhart Baum Special Rapporteur of the Commission on Human Rights on the Situation of Human Rights in the Sudan, UNHCR, 28. März 2003. Im Internet unter: http://www.unhchr.ch/huricane/huricane.nsf/view01/0AA2BFDA489DC1BBC12 56B9800435C02?opendocument [zuletzt aufgerufen am 21. Januar 2007] sowie ders., Report of the Special Rapporteur, Gerhart Baum, submitted in accordance with Commission Resolution 2002/16 on the Situation of Human Rights in the Sudan, UN-Doc. E/CN.4/2003/42.

Regina Bernhard / Hildegard Lingnau, Die Vereinten Nationen und die Darfur Krise, a.a.O. (Fn. 81), S. 168. Vgl. an dieser Stelle die obigen Ausführungen unter Gliederungspunkt C. I. UN-Doc. E/CN.4/DEC/2004/128.

Regina Bernhard / Hildegard Lingnau, Die Vereinten Nationen und die Darfur Krise, a.a.O. (Fn. 81), S. 168. 
$b b$ ) Der Umgang mit der gegenwärtigen humanitären Krise im Sudan illustriert dementsprechend wieder einmal, dass die Verfolgung schwerer, meist systematischer Menschenrechtsverletzungen sowie die Durchsetzbarkeit darauf bezogener Resolutionsentwürfe kaum noch von der konkreten Gewichtigkeit von Menschenrechtsverletzungen in einem Staat abhängt, sondern vielmehr davon, wie es den Regierungsvertretern gelingt, durch politische und regionale Allianzen eine entsprechende Verurteilung zu verhindern oder sie zumindest weitestgehend abzuschwächen. Diese Glaubwürdigkeitskrise der UN-Menschenrechtskommission hatte sicherlich Kofi Annans Vorschlag beflügelt, die Kommission nicht zu reformieren, ${ }^{94}$ sondern durch ein neues Gremium, einen Menschenrechtsrat als eigenständiges Hauptorgan gemäß des Artikel 108 UN-Charta oder als ein Nebenorgan der Vollversammlung zu ersetzen. ${ }^{95}$ Dass in der verabschiedeten Resolution ${ }^{96}$ dann der zweite Vorschlag aufgegriffen wurde, ist insoweit nicht verwunderlich als dass die Einrichtung eines Menschenrechtsrates als Hauptorgan in Anbetracht unterschiedlicher (wirtschafts-)politischer Interessen ständiger Sicherheitsratsmitglieder ${ }^{97}$ eine scheinbar unüberwindliche Hürde bei einer Änderung der UN-Charta dargestellt hätte. Ob und wie nun künftig die von der UN-Menschrechtskommission geschaffenen Instrumente weitergeführt werden, wird der neue Menschenrechtsrat zu entscheiden haben. ${ }^{98}$ Damit geht man allerdings auch das Risiko ein, dass manche erfolgreiche Mechanismen der Kommission von den Mitgliedstaaten zur Disposition gestellt werden könnten. ${ }^{99}$

cc) Dieses Wagnis ist ein unbefriedigendes Ergebnis, betrachtet man zudem die bisherigen und zu erwartenden humanitären Desaster, unter anderem auf dem afrikanischen Kontinent. Ungeachtet der Reformbestrebungen und mit direktem Fokus auf den Sudan, ist daher momentan zu überlegen, die Menschenrechtsarbeit parallel zum Ansatz des monitoring, der Überwachung der Menschenrechtssituation, in Anlehnung an Gerhart R. Baums Anregung, auf eine breite Basis zu stellen. ${ }^{100}$ Dabei ist es völlig zutreffend, dass speziell im Sudan

Zur Reformdiskussion interessant ist u.a. Walter Kälin / Cecilia Jimenez, Reform of the UN Commission on Human Rights [Study commissioned by the Swiss Ministry of Foreign Affairs], Bern/Genf 30. August 2003.

Vgl. United Nations Secretary General Kofi Annan, In Larger Freedom: Towards Development, Security and Human Rights for all, UN-Doc. A/59/2005, para. 181 - 183 sowie Annex IV 8 (e) und ders. UN-Doc. A/59/565, para. 291. Siehe UN-Doc. A/Res/60/251, 15. März 2006, Ziffer 1.

$\mathrm{Zu}$ den (wirtschafts-)politischen Zielsetzungen der 15 UN-Sicherheitsratsmitglieder im Zusammenhang mit der Darfur-Krise siehe, Regina Bernhard / Hildegard Lingnau, Die Vereinten Nationen und die Darfur Krise, a.a.O. (Fn. 81), S. 170 f.

Julia Raue / Beate Rudolf, Bewährtes verteidigen und verbessern, Zur Zukunft der Sondermechanismen der UN-Menschenrechtskommission, Vereinte Nationen 1-2/2006, S. 12.

Ibid.; Gunnar Theissen, Mehr als nur ein Namenswechsel: Der Menschenrechtsrat der Vereinten Nationen, Vereinte Nationen 4/2006, S. 138, 139.

100

Gerhart R. Baum, Sudanesische Menschenrechtsbilanz, a.a.O. (Fn. 77), S. 111, 115. 
verschiedene externe Institutionen ziemlich unkoordiniert operieren. Mit neuen Programmen zur Förderung der Zivilgesellschaften ${ }^{101}$ könnte man so unter der Zielsetzung, etwas von außen mit Hilfe derjenigen von innen, durch nachhaltige Überzeugung, auf die inneren Verhältnisse der Staaten einwirken. ${ }^{102}$ Letztlich also ein pragmatischer Ansatz, um hier die Unfähigkeit der Weltgemeinschaft im Allgemeinen und der bisherigen UN-Menschenrechtskommission im Speziellen zu kompensieren.

\section{Der Sicherheitsrat der Vereinten Nationen}

Selbst der UN-Sicherheitsrat hielt sich erstaunlich lange zurück, obwohl das Repräsentantenhaus der Vereinigten Staaten von Amerika die Menschenrechtsverletzung als Genozid qualifiziert hatte und auch europäische Staaten zu Taten drängten. Erst im Juni 2004 wurde der Darfur-Konflikt im Sudan ernsthaft auf die Agenda des Sicherheitsrates gesetzt, ${ }^{103}$ um Druck auf die GoS, aber auch auf die anderen Parteien des Konflikts, auszuüben. ${ }^{104}$ Dieser schlossen sich dann eine Kette von Resolutionen an, auf die im Folgenden nach Relevanzgesichtspunkten und inhaltlicher Bedeutung eingegangen wird.

\section{a) Resolution 1556 - Kompromiss des kleinsten gemeinsamen Nenners}

Anfang Juli 2004 legten dann die Vereinigten Staaten von Amerika dem Sicherheitsrat einen Resolutionsentwurf vor. Obgleich UN-Generalsekretär Kofi Annan die Vorlage würdigte und den UN-Sicherheitsrat aufforderte baldmöglichst eine Resolution zu verabschieden, dauerte es einige Wochen, ehe am 30. Juli im UN-Sicherheitsrat Resolution 1556 mit 13 von 15 Stimmen ${ }^{105}$ beschlossen wurde. Der ursprüngliche Resolutionsentwurf erfuhr jedoch im Verlauf des Monats durch Schwächung des Resolutionstextes zunehmend an Aussagekraft. Die USA, Großbritannien, Frankreich, Chile und Deutschland sprachen sich angesichts der verheerenden Situation dafür aus, Druck auf Khartum auszuüben und in diesem Sinne rasch eine Resolution zu verabschieden, wohingegen China, Pakistan, Russland und Algerien auf die Kooperationswilligkeit der GoS sowie erzielte Fortschritte ab-

101 Vergleiche dazu Hatem Elliesie, Friedensprozess und Verfassungsentwicklung im Sudan, a.a.O. (Fn. 31), S. 304, wonach noch zu ,oft mit Vertretern zusammen gearbeitet wird, die die intellektuelle, säkulare, oft im "Westen" ausgebildete Elite stellen und sich (sicher) auf dem internationalen Parkett bewegen. In ihrer eigenen Gesellschaft sind sie aber oft nur noch wenig verwurzelt. Damit mangelt es ihnen an der Basis, um effektive politische Bewegungen zu bilden, die Reformen wirkungsvoll einfordern, Interessen der Bevölkerung bündeln und in den politischen Willensbildungsprozess einbinden können“ (m.w.N.).

Siehe Gerhart R. Baum, Sudanesische Menschenrechtsbilanz, a.a.O. (F

03 Vgl. UN-Security Council Resolution 1547, New York 11. Juni 2004, UN-Doc. S/Res/1547 (2004).

104 Yolanda Gamarra / Alejandra Vicente, a.a.O. (Fn. 55), S. 202.

105 China und Pakistan enthielten sich der Stimme. 
stellten und demgemäß für mehr Zeit plädierten. ${ }^{106}$ Hinter den, den gesamten Monat durchziehenden Kontroversen, standen vornehmlich wirtschaftliche Interessen von 6 der 15 Mitglieder des Sicherheitsrates. ${ }^{107}$ So verzichteten die im Sicherheitsrat vertretenen EUStaaten und die USA beispielsweise auf die Bezeichnung des „Genozids“, welche aus der Präambel gestrichen wurde. Selbst die Androhung von „Sanktionen“ wurde durch die Androhung von „Maßnahmen“ (in Verbindung mit Artikel 41 UN-Charta) ersetzt. Beruhend auf Kapitel VII der UN-Charta wurde daneben in der Resolution 1556 der sudanesischen Regierung eine 30-Tage-Frist zur Entwaffnung der Ğannğāwìd gewährt, deutlich darauf hingewiesen, dass die sudanesische Regierung ihre Zivilbevölkerung zu schützen hat ${ }^{108}$ und angedeutet, dass die Konfliktparteien daran gebunden sind ihrer humanitären, völkerrechtlichen Verpflichtung nachzukommen ${ }^{109}$. Genauer betrachtet fällt dabei auf, dass im Kontext des Schutzes der Zivilbevölkerung der Ausdruck „responsibility“ und nicht wie in Bezugnahme auf das humanitäre Völkerrecht „obligation“ verwendet wurde. Stellt letzteres eindeutig eine Pflicht dar, so weist „responsibility“ allenfalls auf eine schwere Verantwortung, eine moralische Verpflichtung hin. ${ }^{110}$ Sicherlich, die Möglichkeit der Androhung von „Maßnahmen nach Artikel 41 UN-Charta“ kann im Grunde denselben Effekt wie „Sanktionen“ nach sich ziehen, außer dass eben die Möglichkeit der militärischen Intervention ausgeschlossen ist. ${ }^{111}$ Doch selbst diese Maßnahmen scheinen angesichts beträchtlicher chinesischer Ölkonzessionen und damit verbunder Investitionen gerade im Hinblick auf das Vetorecht des ständigen Mitglieds China im Sicherheitsrat höchst unwahrscheinlich. ${ }^{112}$ Ferner wurde die GoS anlässlich des Aufenthaltes des UN-

Yolanda Gamarra / Alejandra Vicente, a.a.O. (Fn. 55), S. 210.

Olaf Köndgen, a.a.O. (Fn. 22), S. 16. Zur Positionierung der 15 Sicherheitsratsmitglieder (einschließlich ihrer politischen und wirtschaftlichen Intention) siehe, Regina Bernhard / Hildegard Lingnau, Die Vereinten Nationen und die Darfur Krise, a.a.O. (Fn. 81), S. 170 f; Alex J. Bellamy, Responsibility to Protect or Trojan Horse? The Crisis in Darfur and Humanitarian Intervention after Iraq, Ethics \& International Affairs, 19 (2005/2), S. 31, 45.

108

An dieser Stelle sei nochmals auf die entsprechenden Ausführungen unter Gliederungspunkt C. I.

109

2. verwiesen.

Siehe in diesem Zusammenhang Gliederungspunkt C. I. 3 (,Die humanitäre, völkerrechtliche Verpflichtung des Sudans und die UN").

110 Siehe UN-Security Council Resolution 1556, New York 30. Juli 2004, UN-Doc. S/Res/1556 (2004).

111 Artikel 41 Satz 1 UN-Charta:

Der Sicherheitsrat kann beschließen, welche Maßnahmen - unter Ausschluss von Waffengewalt zu ergreifen sind, um seinen Beschlüssen Wirksamkeit zu verleihen; er kann die Mitglieder der Vereinten Nationen auffordern, diese Maßnahmen durchzuführen. [...]

112 So besteht beispielsweise eine von der China National Petroleum Corporation (CNPC) gebaute Pipeline, welche zunächst Öl aus West-Kordofan und später aus Süd-Darfur pumpen soll. Auch an den noch nicht erschlossenen Konzessionen im so genannten Block 12, der das gesamte NordDarfur sowie Teile von West- und Süd-Darfur abdeckt, hat China u.a. neben Russland Interesse bekundet. 
Generalsekretärs Kofi Annan erneut angehalten den 16 schriftlich fixierten Zusicherungen ${ }^{113}$ des Joint Communiqué vom 3. Juli 2004 zwischen ihr und den Vereinten Nationen ${ }^{114}$ nachzukommen.

So konnte sich auch über ein Jahr nach Ausbruch der Eskalation die internationale Gemeinschaft nicht zu einem greifbaren Ergebnis durchringen. Das Austarieren der Stimmen und die Form der verwendeten Diktion hatten letztlich zur Folge, dass Vertreibung, Zerstörung, Vergewaltigung, Mord und Totschlag weiterhin als die bestimmenden Elemente Darfur prägten. Dennoch wurde die Resolution in der Öffentlichkeit mit der Begründung, es sei „um das Machbare“ und die „breite Mehrheit“ gegangen, teilweise als „,beachtlich“ bewertet. Sie sei ein Signal an Khartum, dass nun der Sicherheitsrat die Angelegenheit an sich ziehe. Dass dem nicht so war, deutete sich schon früh durch Verlautbarungen einiger Mitglieder der Bašĭr-Administration an und zeigte sich spätestens nach Ablauf der Frist, welche ohne substantiellen Fortschritt verstrich.

\section{b) Resolution 1564 / International Commission of Inquiry on Darfur}

Daraufhin befasste sich der Sicherheitsrat am 18. September 2004 zwar erneut mit der Darfur-Krise und verabschiedete Resolution 1564 ohne Gegenstimmen, ${ }^{115}$ aber mit vier Enthaltungen. ${ }^{116}$ Darin wurde die sudanesische Regierung ausdrücklich aufgefordert ,dem Klima der Straflosigkeit in Darfur" entgegenzuwirken und die Verantwortlichen der Gräueltaten einschließlich derer der $P D F$ und $\breve{G} a n n g \check{a} \bar{a} w \bar{\imath} d$ für ihre weit verbreiteten Menschenrechtsverletzungen und Verletzungen des humanitären Völkerrechts zur Rechenschaft zu ziehen. Ferner wurden die Maßnahmen nach Artikel 41 UN Charta auf den Ölsektor spezifiziert, was aber insgesamt wegen der wirtschaftlichen Verflechtungen mit ständigen Sicherheitsratsmitgliedern in diesem, an Bedeutung zunehmenden, Energiesektor inhaltlich erneut als mindestens genauso schwach, wenn nicht noch schwächer zu bewerten ist, als die wenigstens noch mit einer Frist versehene Resolution vom 30. Juli 2004. ${ }^{117}$

113 Unter anderem die Ǧannǧāwīd zu entwaffnen, die Sicherheit in Darfur wiederherzustellen und ungehinderten Zugang von internationalen Hilfsorganisationen zum Krisengebiet zu gewährleisten.

114 Siehe Joint Communique of the Government of the Sudan and the United Nations on the Occasion of the Visit of the Secretary-General to the Sudan, Khartum 3, Juli 2004, UN-Doc. S/2004/635 Annex.

115 UN-Security Council Resolution 1564, New York 18. September 2004, UN-Doc. S/Res/1564 (2004).

116 Algerien, China, Pakistan, Russland.

117 So auch Regina Bernhard / Hildegard Lingnau, Die Vereinten Nationen und die Darfur Krise, a.a.O. (Fn. 81), S. 171. Siehe ferner Alex J. Bellamy, Responsibility to Protect or Trojan Horse? The Crisis in Darfur and Humanitarian Intervention after Iraq, a.a.O. (Fn. 107), S. 31, 46 f. 
aa) Einsetzung einer unabhängigen Untersuchungskommission

Immerhin, Amnesty Internationals Appell ${ }^{118}$ und die sich darauf aufbauende Empfehlung des Sonderberichterstatters der UNCHR für den Sudan, ${ }^{119}$ eine internationale unabhängige Untersuchungskommission für die Darfur-Region einzusetzen, konnte endlich durchtaktiert werden. Durch den Beschluss wurde die 5-köpfige sog. International Commission of Inquiry on Darfur zusammengestellt, welche am 25. Oktober 2004 ihre Arbeit aufnahm und die Region mehrmals besuchte. ${ }^{120}$ Dabei wurde sie von dem Personal des Hohen Kommissariats der Vereinten Nationen für Menschenrechte (OHCHR) unterstützt. Ziel war es herauszufinden, wer die Verantwortlichen der Gewalttaten im Rahmen des Darfur-Konflikts im Zeitraum von Februar 2003 bis Mitte Januar 2005 sind, wo sie gegen internationales Recht und Menschenrechte verstoßen haben, sowie außerdem spezifisch zu ermitteln, ob Akte des Genozids aufgetreten sind oder nicht.

\section{bb) Ergebnis der unabhängigen Untersuchungskommission}

Die International Commission of Inquiry on Darfur hat schließlich dem Generalsekretär der Vereinten Nationen Kofi Annan am 25. Januar 2005 einen 176 Seiten umfassenden Bericht übergeben, ${ }^{121}$ in dem zwar keine Anhaltspunkte für Völkermord durch die sudanesische Regierung festgestellt wurden, wohl aber, dass Regierungstruppen und Milizen Kriegsverbrechen und Verbrechen gegen die Menschlichkeit begangen haben. Gleichzeitig hat die Kommission empfohlen, dass der Sicherheitsrat der Vereinten Nationen den Sachverhalt an den Internationalen Strafgerichtshof verweist, damit dieser auch ohne Zustimmung des UN-Mitglieds Sudan gemäß Artikel 13 (b) seines Statuts ${ }^{122}$ in Verbindung mit

118 Amnesty International, Sudan: Urgent Call for Commission of Inquiry in Darfur as Situation Deteriorates, London 21. Februar 2003, AI-Index AFR 54/004/2003, a.a.O. (Fn. 64).

119

Gerhart Baum, Statement by Mr. Gerhart Baum Special Rapporteur of the Commission on Human Rights on the Situation of Human Rights in the Sudan, UNHCR, 28. März 2003, a.a.O. (Fn. 88).

So besuchte die Kommission den Sudan vom 7. bis 21. November 2004 sowie vom 9. bis 16. Januar 2005. Dies schloss Reisen in die drei Darfur-Provinzen ein, wobei eine Arbeitsgruppe zu Untersuchungszwecken von November 2004 bis Januar 2005 dort verblieb.

International Commission of Inquiry on Darfur, Report of the International Commission of Inquiry on Darfur to the United Nations Secretary-General, Genf 2005.

Artikel 13 Römisches Statut des Internationalen Strafgerichtshofes:

Der Gerichtshof kann in Übereinstimmung mit diesem Statut seine Gerichtsbarkeit über ein in Artikel 5 bezeichnetes Verbrechen ausüben, wenn

(a) eine Situation, in der es den Anschein hat, dass eines oder mehrere dieser Verbrechen begangen wurden, von einem Vertragsstaat nach Artikel 14 dem Ankläger unterbreitet wird,

(b) eine Situation, in der es den Anschein hat, dass eines oder mehrere dieser Verbrechen begangen wurden, vom Sicherheitsrat, der nach Kapitel VII der Charta der Vereinten Nationen tätig wird, dem Ankläger unterbreitet wird, oder

(c) der Ankläger nach Artikel 15 Ermittlungen in Bezug auf eines dieser Verbrechen eingeleitet hat. 
Kapitel VII der UN Charta gegebenenfalls tätig werden kann. ${ }^{123}$ An diese Beschlüsse wäre auch der Sudan als UN-Mitglied nach Maßgabe des Artikels 25 UN-Charta gebunden. ${ }^{124}$

\section{c) Auswirkung der Resolution 1574 - Gewalt im Schatten des Naivasha-Prozesses}

Das kurz zuvor am 9. November 2004 unter der Schirmherrschaft der Afrikanischen Union in der nigerianischen Hauptstadt Abuja unterzeichnete Waffenstillstandsabkommen ${ }^{125}$ zwischen der GoS und der SLM/A sowie SJEM wurde im Anschluss an die Sitzungen des UN-Sicherheitsrates der Vereinten Nationen in der kenianischen Hauptstadt Nairobi vom 18. bis 19. November 2004 und als Folge der dort verabschiedeten Resolution 1574 Makulatur. Anders als die vorherigen Resolutionen befasst diese sich in erster Linie mit dem Nord-Süd-Konflikt und dem damit einhergehenden Friedensprozess. ${ }^{126}$ Den Friedensbemühungen im Sudan Ausdruck verleihend, verzichtete der UN-Sicherheitsrat, um die GoS zum Abschluss der Friedensverhandlungen mit der $S P L A / M$ zu ermutigen, auf die Androhung jeglicher Maßnahmen. Dies wirkte sich insofern direkt auf den Darfur-Konflikt aus, als die dortigen Protagonisten der bewaffneten Eskalation neue Offensiven starteten und die Entwicklungen in Darfur daraufhin einen besorgniserregenden Verlauf nahmen. Insbesondere der SLA und der SJEM wurde dies als Versuch ausgelegt, die internationale Aufmerksamkeit vom Nord-Süd-Konflikt zurück auf Darfur zu lenken und die GoS geriet ihrerseits in den begründeten Verdacht, den milderen Wortlaut der Resolution als Signal aufzufassen, dass ihr neue militärische Handlungsspielräume in Darfur offen stehen. ${ }^{127}$

\section{d) Evaluation des UN-Sicherheitsrates in der Darfur-Krise}

Insgesamt lässt sich mit Bezug auf den UN-Sicherheitsrat feststellen, dass es ihm nicht gelungen ist, eine Resolution zu verabschieden, die ein schnelles und zugleich effektives

An dieser Stelle wird nochmals auf obige Ausführung (C. I. 1.) verwiesen: Der Sudan hat im Jahre 2000 das Römische Statut für einen Internationalen Strafgerichtshof unterzeichnet.

124 Sascha Rolf Lüder, Die Geschichte der Verfolgung von Kriegsverbrechen, in: Horst Fischer / Ulrike Froissart / Wolff Heintschel von Heinegg / Christian Raap [Hrsg.], Krisensicherung und Humanitärer Schutz - Crisis Management and Humanitarian Protection (Festschrift für Dieter Fleck), Berlin 2004, S. 365, 372. Siehe ferner Dan Sarooshi, The Peace and Justice Paradox: The International Criminal Court and the UN-Security Council, in: Dominik Mc Goldrick / Peter Rowe / Eric Donnely [Hrsg.], The Permanent International Criminal Court: Legal and Policy Issues, Oxford 2004, S. 104.

Protocol between the Government of the Sudan (GoS), the Sudan Liberation Movement/Army (SLM/A) and the Justice and Equality Movement (JEM) on the Improvement of the Humanitarian Situation in Darfur. Siehe http://www.africa-union.org/DARFUR/Agreements/MAP0013.PDF [zuletzt aufgerufen am 22. Januar 2007].

127

UN-Security Council Resolution 1574, New York 19. November 2004, UN-Doc. S/Res/1574 (2004).

Denis M. Tull, a.a.O. (Fn. 40), S. 5. 
Mittel gegen die Menschenrechtsverletzungen in Darfur ermöglicht hätte. Die verabschiedeten Resolutionen sind zwar - um die „Signal“-Wirkung aufzugreifen - wichtig, aber die darin enthaltenen „Maßnahmen“ reichten bei Weitem nicht aus, um die humanitäre Katastrophe auch nur ansatzweise einzudämmen. Dies ist, nach Ruanda 1994, ein deutliches Zeichen dafür, dass der Sicherheitsrat seiner Pflicht zur Wahrung des Weltfriedens nach Maßgabe des Artikels 24 UN-Charta durch schnelles und wirksames Handeln nicht nachgekommen ist und es in seiner bisherigen Form wohl auch nicht kann. Wenn zwischen den Vetomächten keine Einigkeit herrscht, dann kann der Rat eben nur den kleinsten gemeinsamen Nenner beschließen. Die Stellung ständiger Mitglieder des Sicherheitsrates wie Russland $^{128}$ und $\mathrm{China}^{129}$ mit ihren nationalen Interessen und starken wirtschaftlichen Ambitionen im Sudan machen deutlich, dass nur eine wirkliche Reform des Sicherheitsrates an dem Problem, der uneingeschränkten Nutzung oder zumindest Androhung ihres Vetorechts, etwas ändern kann.

\section{Der Internationale Strafgerichtshof}

\section{Resolution 1593 - Sicherheitsratsverweisung an den IStGH}

Über zwei Jahre nach Ausbruch der gewalttätigen Eskalation in Darfur konnte sich der UNSicherheitsrat nach langem Zögern in Resolution $1593(2005)^{130}$ zur Überweisung des „Falles“ Darfur wegen der „Situation im Sudan“, welche „eine Bedrohung für den internationalen Frieden und die Sicherheit darstellt“ auf Basis des Kapitels VII der UN-Charta ${ }^{131}$ an den $I S t G H,{ }^{132}$ in Anlehnung an die Empfehlung der International Commission of Inquiry on Darfur, durchringen. ${ }^{133}$ Eine katastrophale Bilanz aus der maßgeblichen, humanitären Perspektive. Völkerrechtlich betrachtet ein Meilenstein: Es ist das erste Mal, dass

Russland betreibt neben seinem Öl-Engagement regen Waffenhandel mit dem Sudan. So hat Russlands MiG Aircraft Cooperation während der Darfur-Krise, mitten in den Verhandlungen zur UN-Sicherheitsratsresolution 1556, am 20. Juli 2004, zwölf MiG Fulcrum Kampfflugzeuge an die sudanesische Regierung geliefert.

Vgl. hier ggf. erneut Regina Bernhard / Hildegard Lingnau, Die Vereinten Nationen und die Darfur Krise, a.a.O. (Fn. 81), S. 170 f.

130 UN-Security Council Resolution 1593, New York 31. März 2005, UN-Doc. S/Res/1593 (2005).

131 Ibid., Absatz 5 und 6 der Präambel.

132 Zur Sicherheitsratsverweisung an den IStGH siehe auch Matthew Happold, Darfur, the Security Council, and the International Criminal Court, International and Comparative Law Quarterly (ICQL), 55 (2006/1), S. 226 ff; Robert Cryer, Sudan, Resolution 1593, and International Criminal Justice, Leiden Journal of International Law, 19 (2006), S. 195, 203 ff.

Der französische Textentwurf wurde mit elf zu null Stimmen bei vier Enthaltungen (Algerien, Brasilien, China, USA) angenommen. Siehe UN-Sicherheitsrat, Presseveröffentlichung, UN-Doc. SC/8351, New York 31. 3. 2005. 
der Sicherheitsrat der Vereinten Nationen einen Fall an den Internationalen Strafgerichtshof in Den Haag gemäß Artikel 13 (b) des Statuts des $I S t G H$ weiterleitet. ${ }^{134}$ In diesem Sinne wurde in gewisser Weise (UN-)Geschichte geschrieben. ${ }^{135}$ Es ist bemerkenswert, dass der $I S t G H$ bereits im ersten Jahr seiner Operationabilität ${ }^{136}$ einen Fall durch den UNSicherheitsrat überwiesen bekommt und die USA sich durch ihre Stimmenenthaltung, jedenfalls im Darfur-Kontext, von ihrer starr ideologischen Fixierung gegen den IStGH lösten. ${ }^{137}$ Allerdings ist auch anzumerken, dass die US-Enthaltung mit einer erheblichen Schwächung der Resolution und ihrer Legitimation einhergeht: Personal von UN-Operationen oder solchen der Afrikanischen Union (AU) oder von diesen Organisationen autorisierte Operationen sind von der Zuständigkeit des $I S t G H$ ausgenommen, wenn sie Staaten angehören, die das Statut nicht ratifiziert haben oder ihm nicht beigetreten sind. ${ }^{138}$

\section{Die Funktion und Rolle des Internationalen Strafgerichtshofes}

\section{Das Prinzip der Komplementarität}

Die Präambel und Artikel 1 des Statuts des $I S t G H$ bezeichnen den Internationalen Strafgerichtshof als eine internationale Einrichtung, welche „shall be complementary to national criminal jurisdiction “. Dieses komplementäre Verhältnis zwischen dem IStGH und der nationalen Strafgerichtsbarkeit bedeutet, dass er - anders als die zwei Ad-hoc-Tribunale für das ehemalige Jugoslawien (ICTY) ${ }^{139}$ und Ruanda (ICTR) ${ }^{140}$ - über keine vorrangige Gerichtsbarkeit gegenüber nationale Behörden verfügt. ${ }^{141}$ Er spielt eine subsidiäre Rolle

Rosanna Lipscomb, Restructuring the ICC Framework to Advance Transitional Justice: A Search for a Permanent Solution in Sudan, Columbia Law Review, 106 (2006/1), S. 182, 185.

Max Du Plessis / Christopher Gevers, Darfur goes to the International Criminal Court (Perhaps), African Security Review, 14 (2), Pretoria 2005, S. 23; Annalisa Ciampi, The International Criminal Court, The Law \& Practice of International Courts and Tribunals, Leiden 2005/4, S. 335.

Vgl. Annalisa Ciampi, The International Criminal Court, The Law \& Practice of International Courts and Tribunals, Leiden 2004/3, S. 143.

137 Dies läst sich wohl darauf zurückführen, dass die USA am deutlichsten von allen Ratsmitgliedern eine Verfolgung der Verbrechen in der sudanesischen Provinz gefordert hatten.

138

So wie beispielsweise der Sudan, aber auch die Vereinigten Staaten. Zu den Vertragsstaaten (Stand: 1. Januar 2007) siehe http://www.icc-cpi.int/statesparties.html [zuletzt aufgerufen am 22.

139 Januar 2007].

140 Vgl. Artikel 8 des ICTR-Statuts.

141 Einschließlich der Gerichte und sonstiger Ermittlungsbehörden in strafrechtlichen Angelegenheiten; Immi Tallgren, Completing the "International Criminal Order"; The Rhetoric of International Repression and the Notion of Complementarity in the Draft Statute for an International Criminal Court, Nordic Journal of International Law (Nord. J. Int'l L.), 67 (1998), S. 107, 120. 
und ergänzt die innerstaatliche Ermittlung und Strafverfolgung der gravierendsten Verbrechen von internationalem Interesse gemäß Artikel 5 des Statuts des $I S t G H .{ }^{142}$ Jeder Staat, dessen Staatsangehörige eines Verbrechens nach diesem Artikel beschuldigt werden, hat es in der Hand, selbst ein ernsthaftes Strafverfahren einzuleiten und damit die Gerichtsbarkeit des $I S t G H$ zu blockieren. ${ }^{143}$

Davon normiert allerdings Artikel 17 des Statuts des IStGH eine Ausnahme. Der Internationale Strafgerichtshof kann nämlich ein Verfahren ungeachtet gegebener nationaler Strafhoheit durchführen, wenn der an sich zuständige Staat ,nicht willens oder nicht in der Lage ist, die Ermittlungen oder die Strafverfolgung ernsthaft durchzuführen“, oder wenn die Entscheidung, die betreffende Person nicht strafrechtlich zu verfolgen, ,das Ergebnis des mangelnden Willens oder des Unvermögens ...[ist], eine Strafverfolgung durchzuführen“. $\mathrm{Ob}$ dies im konkreten Einzelfall so ist, obliegt dem IStGH in einer Entscheidung, die (bei ihm selbst) nach Artikel 19 IStGH-Statut angefochten werden kann. Dabei steht ihm aber natürlich ein erheblicher Ermessensspielraum zu. ${ }^{144}$

\section{Die grundsätzliche und die konkrete Zuständigkeitsregel}

Hinsichtlich der prinzipiellen Zuständigkeit des $I S t G H$ gilt, dass nach der Regelung des Artikel 12 Absatz 1 IStGH-Statut der Beitritt eines Staates zum römischen Gründungsvertrag des Internationalen Strafgerichtshofes auch eine grundsätzliche Akzeptanz des entsprechenden Staates gegenüber der Zuständigkeit und Jurisdiktion des $I S t G H$ darstellt. ${ }^{145}$ Der $I S t G H$ leitet also dementsprechend seine Zuständigkeit aus einem multilateralen Vertrag ab. ${ }^{146}$ Diese Regelung kam jedoch im Falle Darfurs, wie bereits dargestellt wurde, nicht zur

142

Markus Benzing, The Complementarity Regime of the International Criminal Court: International Criminal Justice between State Sovereignty and the Fight against Impunity, Max Planck Yearbook of United Nations law (Max Planck UNYB), Leiden 2003, S. 591 f. (m.w.N.). Siehe in diesem Zusammenhang auch die Ausführungen von Leeladhara Bhandary, International Criminal Court: Developments in Prosecution, Indian Journal of International Law, 45 (2005/2), S. 256-262.

Torsten Stein, Der Internationale Strafgerichtshof - Start über Stolpersteine, in: Horst Fischer / Ulrike Froissart / Wolff Heintschel von Heinegg / Christian Raap [Hrsg.], Krisensicherung und Humanitärer Schutz - Crisis Management and Humanitarian Protection (Festschrift für Dieter Fleck), Berlin 2004, S. 559 ff.; siehe dazu auch Martii Koskenniemi, Between Impunity and Show Trials, Max Planck UNYB, Leiden 2002, S. 1 ff.

144 Torsten Stein, a.a.O. (Fn. 143), S. 562; Markus Benzing, a.a.O. (Fn. 142), S. 592; Denis Basak, Die Zuständigkeitsregeln internationaler Strafgerichte und Art. 101 GG, Frankfurt a. M. 2004, S. $50 \mathrm{f}$.

145 Frank Hoffmeister / Sebastian Knocke, Das Vorermittlungsverfahren vor dem Internationalen Strafgerichtshof - Prüfstein für die Effektivität der neuen Gerichtsbarkeit im Völkerstrafrecht, ZaöRV, Stuttgart 1999, S. 785, 795; Denis Basak, a.a.O. (Fn. 144), S. 52.

Barbara Lüders, Die Strafbarkeit von Völkermord nach dem Römischen Statut für den Internationalen Strafgerichtshof, Berlin 2004, S. 25; Kerstin Karoline Retzko, Internationaler Strafgerichts- 
Anwendung. Hier kam Artikel 13 (b) des $I S t G H$-Statutes zum Tragen, wonach der UNSicherheitsrat unter Berufung auf Kapitel VII der UN-Charta den IStGH anrief.

\section{Die Einleitung des Ermittlungsverfahrens}

Gemäß Artikel 53 IStGH-Statut und Rule 104 of the Rules of Procedure and Evidence begann die Office of the Prosecutor (OTP) unverzüglich Ermittlungen durchzuführen und zusätzliche Informationen zu eruieren. ${ }^{147}$ Die OTP erhielt ebenfalls den Bericht der International Commission of Inquiry on Darfur und Unterlagen, welche diese gesammelt hatte, sowie eine Liste von Namen einer Anzahl von Individuen, die von der Kommission als verdächtige Personen bezüglich schwerwiegender internationaler Verbrechen in Darfur beschuldigt werden. Diese Liste ist jedoch nicht verbindlich für den Ankläger (Prosecutor). Er/sie soll seine/ihre eigene, unabhängige Ermittlung nicht nur auf der Basis der Dokumentation der International Commission of Inquiry on Darfur durchführen, sondern auch auf Informationen anderer Quellen zurückgreifen. ${ }^{148}$

\section{Gegenstand der Jurisdiktion des Gerichtshofes}

Wie bereits angedeutet, bestimmt Artikel 5 Absatz 1 IStGH-Statut, dass sich die Gerichtsbarkeit des Strafgerichtshofes auf die schwersten Verbrechen beschränkt, welche die internationale Gemeinschaft als Ganzes betreffen. Die vier Kernverbrechen sind Völkermord (Artikel 6), Verbrechen gegen die Menschlichkeit (Artikel 7), Kriegsverbrechen (Artikel 8) und das noch zu definierende Verbrechen der Aggression ${ }^{149}$. Mit der Formulierung der von den Artikeln 6 bis 8 erfassten Tatbestände dieses Statuts wurde kein neues materielles Recht geschaffen; ${ }^{150}$ die einzelnen Verbrechenstatbestände konkretisieren - jedenfalls im Kern - nach dem Willen des Verfassers des Statuts vielmehr nur bereits bestehendes Völkergewohnheitsrecht. ${ }^{151}$

hof befasst sich mit dem Massenmord im Sudan - ein neuer Fall für ein bislang untätiges Gericht, NJW, Frankfurt a.M. 31/2005, S. XVIII.

147

Annalisa Ciampi, The International Criminal Court, The Law \& Practice of International Courts and Tribunals, Leiden 2005/4, S. 335, 360.

148

International Criminal Court - Office of the Prosecutor, Presseveröffentlichung, List of Names of Suspects in Darfur opened by the ICC OTP, Den Haag 11. April 2005. Siehe http://www.icccpi.int/press/pressreleases/101.html [zuletzt aufgerufen am 22. Januar 2007].

Siehe Artikel 5 Absatz 1 lit. d i.V.m. Absatz 2 des Statuts des $I S t G H$.

150 Kelly Dawn Askin, Crimes within the Jurisdiction of the International Criminal Court, CLF 10 (1999), S. 33; Lyal S. Sunga, The Crimes within the Jurisdiction of the International Criminal Court (Part II, Articles 5-10), European Journal of Crime, Criminal Law and Criminal Justice 151 (EJCCLCJ) 6 (1998), S. 377.

Barbara Lüders, a.a.O. (Fn. 146), S. 24. 


\section{Der Fall Darfur am IStGH - Ein Ausblick}

Die mutmaßlich begangenen Verbrechen, welche in Darfur durch die International Commission of Inquiry on Darfur dokumentiert wurden, erfüllen nach deren Ansicht die im Römischen Statut des Internationalen Strafgerichtshofes in Artikel 7 (1), Artikel 8 (1) und (2) f statuierten Verbrechen. ${ }^{152} \mathrm{Ob}$ darüber hinaus womöglich in späteren Verfahren nun doch ein Völkermord nach Artikel 6 IStGH-Statut angenommen wird, bleibt abzuwarten. Aus Sicht des $I S t G H$ wird sich die Diskussion der Strafverfolgung und Verbrechenskategorisierung im Allgemeinen wohl weniger mit dem „Ob“ (individueller) strafrechtlicher Verantwortlichkeit aufhalten müssen als vielmehr mit dem „Wie“, nämlich den tatbestandlichen Voraussetzungen einer solchen Verantwortlichkeit, die sich ja gerade in subjektiver Hinsicht mit Beweisschwierigkeiten konfrontiert sieht. ${ }^{153}$ Diese können nur und werden sicherlich auch durch den Rückgriff auf - auf Tatsachen beruhenden - Beweisvermutungen überwunden werden können. ${ }^{154}$ Letztlich kann es aber dahinstehen, ob die Verbrechenskategorie des Genozids als spezifischer Tatbestand oder der Sammelbegriff der Verbrechen gegen die Menschlichkeit (crime against humanity) vorliegen wird, denn die völkerstrafrechtliche Rechtsprechung erachtet diese beiden Verbrechenskategorien ohnehin für gleich schwerwiegend. ${ }^{155}$ Keine Zweifel dürften jedenfalls an der völkerstrafrechtlichen, in dieser Form bisher unbekannten Anwendungsschwelle, der „lang anhaltenden“ (protracted) bewaffneten Konflikte nicht internationalen Charakters des Artikel 8 Absatz 2 (f) IStGHStatut, ${ }^{156}$ bestehen. Im Grunde wird es, abschließend, maßgeblich von der praktischen Umsetzung des Komplementaritätsgrundsatzes abhängen. Ein Gericht zur Verfolgung der in Darfur begangenen Verbrechen wurde im Sudan zwar geschaffen, ${ }^{157}$ angesichts der geringen offiziellen Kooperationsbereitschaft des Sudans wird der Internationale Strafge-

International Commission of Inquiry on Darfur, Report of the International Commission of Inquiry on Darfur to the United Nations Secretary-General, Genf 2005, S. 5.

Dazu insbesondere Cherif M. Bassiouni, The Normative Framework of International Humanitarian Law: Overlaps, Gaps and Ambiguities, Transnational Law \& Contemporary Problems (TransL\&CP), Iowa 1998, S. 199, 213.

Dazu ebenfalls, ICTR, The Prosecutor v. Jean-Paul Akayesu, Entscheidung vom 2. September 1998 (Case No. ICTR-96-4-T), para. 523; ICTR, Entscheidung vom 6. Dezember 1999, The Prosecutor v. Georges Anderson Nderubumwe Rutaganda, (Case No. ICTR-96-3), para. 58 ff. (insb. 60) sowie ICTY, The Prosecutor v. Goran Jelisić, Entscheidung vom 14. Dezember 1999 (Case No. IT-95-10-T), para. 79 ff. (insb. 84-87).

Vgl. dazu ICTR, Trial Chamber, Entscheidung vom 5. Februar 1999, The Prosecutor v. Omar Serushago (Case No. ICTR-98-39-S), para. 14.

156 Dazu Kai Ambos, Zur Bestrafung von Verbrechen im internationalen, nicht internationalen und internen Konflikt; in: Jana Hasse / Erwin Müller / Patricia Schneider [Hrsg.], Humanitäres Völkerrecht: politische, rechtliche und strafgerichtliche Dimensionen, Baden-Baden 2001, S. 325, 345.

157

Manoj Kumar Sinha, Crisis in Darfur: International Response, Indian Journal of International Law, 45 (2005/3), S. 389, 396. 
richtshof aber wohl dennoch darauf angewiesen sein, dass der UN-Sicherheitsrat gegebenenfalls seine Verweisung entschieden bekräftigt, gar noch deutlicher auf deren Einhaltung insistiert.

\section{E. Fazit}

Argumentativ wird jedenfalls im Sudan innerhalb der "Regierung der Nationalen Einheit" $(G o S)^{158}$ durch Mitglieder der nordsudanesischen Regierungspartei die Auffassung vertreten, dass ein möglicherweise, nach der wohl als gescheitert zu betrachtenden African Union Mission in Sudan (AMIS) Ende 2006, ersatzweises Mandat der Vereinten Nationen im Jahre 2007, als verlängerten Arm des Internationalen Strafgerichtshofes zu betrachten sei. Dabei wird auch darauf verwiesen, dass die Umsetzung des Comprehensive Peace Agreements $(C P A)$ angesichts der zerstrittenen Rebellen unmöglich sei und eine Mission der Vereinten Nationen schon deshalb nicht zur Debatte stehe. ${ }^{159}$ Außerdem wird, wenngleich auch innerhalb der GoS äußerst umstritten, ${ }^{160}$ die mögliche UN-Einmischung in Darfur in die inneren Angelegenheiten des (souveränen) Sudan ${ }^{161}$ u.a. als eine Form des Neokolonialismus verstanden. ${ }^{162}$ Falls - wovon höchstwahrscheinlich auszugehen ist - China und Russland aus den dargelegten Gründen nicht gewillt sind, die sudanesische Regierung

Diese setzt sich maßgeblich aus der National Congress Party - NCP (al-mü’tamar al-wataniyy) und der (südsudanesischen) Sudan People's Liberation Movement (SPLM) zusammen. Zur proportionalen Zusammensetzung siehe Hatem Elliesie, Friedensprozess und Verfassungsentwicklung im Sudan, VRÜ 38 (2005), S. 276, 286 (m.w.N.).

Vgl. Sebastian Wadle, Die African Mission in Sudan: Schlüssel für den Frieden in Darfur, SWPAktuell, 39 (August 2006), Berlin 2006, S. 1f. Siehe auch Hāny Raslān, ’azmat Dārfūr wa alqarār 1706..al-’ab`ad wa at-tadā'iyyat, in: as-siyāsa ad-dawliyya, 166, Oktober 2006, Cairo 2006, S. $182-187$.

Auch zum Einsatz der UN-Friedenstruppen nach Ablauf des (verlängerten) Mandats der Friedenstruppe der Afrikanischen Union bis zum Jahresende 2006 nimmt Staatspräsident 'Umar Hasan Aḥmad al-Bašīr (NCP), mit Verweis auf das Irak Debakel, eine ablehnende Haltung ein (vgl. u.a. Agence France Presse, 3. November 2006). Zum Standpunkt vom 1. Vizepräsidenten Salva Kiir Mayardit (SPLM) siehe das Interview von Mụ̣mmad al-Ḥasan Ạ̣mad und Muṣtafā Siry mit Salva Kiir Mayardit, in: aš-Šarq al-' Awsaț, London 13. November 2006.

Siehe dazu bspw. das Interview von Mụ̣mmad Sayyid Muḥmmad al-Ḥasa mit Ibrāhīm Aḥmad 'Umar, in: aš-Šarq al-'Awsat, London 7. Oktober 2006. Ergänzende Anmerkung des Verfassers: Am 20. Oktober 2006 wurde der Sondergesandte des UN-Generalsekretärs für Sudan, Johannes Pieter Pronk, zur Persona non grata erklärt (Siehe u.a. Frankfurter Allgemeine Zeitung, UNGesandter Persona non grata, Nr. 245, Frankfurt 21. Oktober 2006, S. 6).

Dazu Robert Cryer, Sudan, Resolution 1593, and the International Criminal Justice, Leiden Journal of International Law, 19 (2006), S. 195, 218 ff; Paul D. Williamas / Alex J. Bellamy, The Responsibility to Protect and the Crisis in Darfur, Security Dialogue, 36 (2005/1), S. 27, 36; ähnlich auch Ahmad Ibrāhīm Mạ̣mūd, al- 'ab`ad al-`askariyya ’azmat našara al-qūwāt ad-dawliyya fī Dārfūr, in: as-siyāsa ad-dawliyya, 166, Oktober 2006, Cairo 2006, S. 188, 191 f. 
nachdrücklicher zur Befolgung zu den völkerrechtlichen Verpflichtungen zu bewegen, werden Zugeständnisse an Khartum aller Voraussicht nach unvermeidlich sein. Die internationale Gemeinschaft wird daher vermutlich nicht darum herumkommen, eine strafrechtliche Verfolgung sowohl von Mitgliedern der sudanesischen Regierung als auch der Rebellenführung in den nächsten zwölf Monaten auszusetzen. ${ }^{163}$ Schließlich hängt von der Stabilität der sudanesischen Regierung, welcher mittlerweile auch Vertreter aus dem Südsudan angehören, ${ }^{164}$ auch die Konsolidierung des südlichen Sudan ab. ${ }^{165}$

Was schlussfolgernd verbleibt, ist die Frage, wie die Weltgemeinschaft künftig friedensstiftend auf Konflikte nicht internationalen Charakters diesen Ausmaßes im Rahmen des Völkervertragsrechtes und Völkergewohnheitsrechtes rasch und effektiv einwirken kann. Selbst nach dem ruandischen Genozid vor nunmehr schon über 10 Jahren gibt der sudanesische Darfur-Konflikt keine Antwort auf diese Frage, jedenfalls keine ermutigende.

Vgl. Artikel 16 Römisches Statut des Internationalen Strafgerichtshofes:

Richtet der Sicherheitsrat in einer nach Kapitel VII der Charta der Vereinten Nationen angenommen Resolution ein entsprechendes Ersuchen an den Gerichtshof, so dürfen für einen Zeitraum von 12 Monaten keine Ermittlungen und keine Strafverfolgung aufgrund dieses Statuts eingeleitet oder fortgeführt werden; das Ersuchen kann vom Sicherheitsrat unter den selben Bedingungen erneuert werden.

164 Siehe Fn. 158; Sebastian Wadle, Die African Mission in Sudan: Schlüssel für den Frieden in 165 Darfur, SWP-Aktuell, 39 (August 2006), Berlin 2006, S. 4.

Zur Situation Ende 2006/Anfang 2007 siehe Darfur und die Ohnmacht der Südsudanesen: Gespräch mit dem Präsidentenberater Bona Malwal, Neue Züricher Zeitung (Internationale Ausgabe), Nr. 288, 11. Dezember 2006, S. 3. 